Prepared for the U.S. Department of Energy

under Contract DE-AC05-76RL01830

\title{
GIS Framework for Large River Geomorphic Classification to Aid in the Evaluation of Flow-Ecology Relationships
}

CR Vernon

EV Arntzen

MC Richmond

RA McManamay ${ }^{1}$

TP Hanrahan

CL Rakowski

February 2013

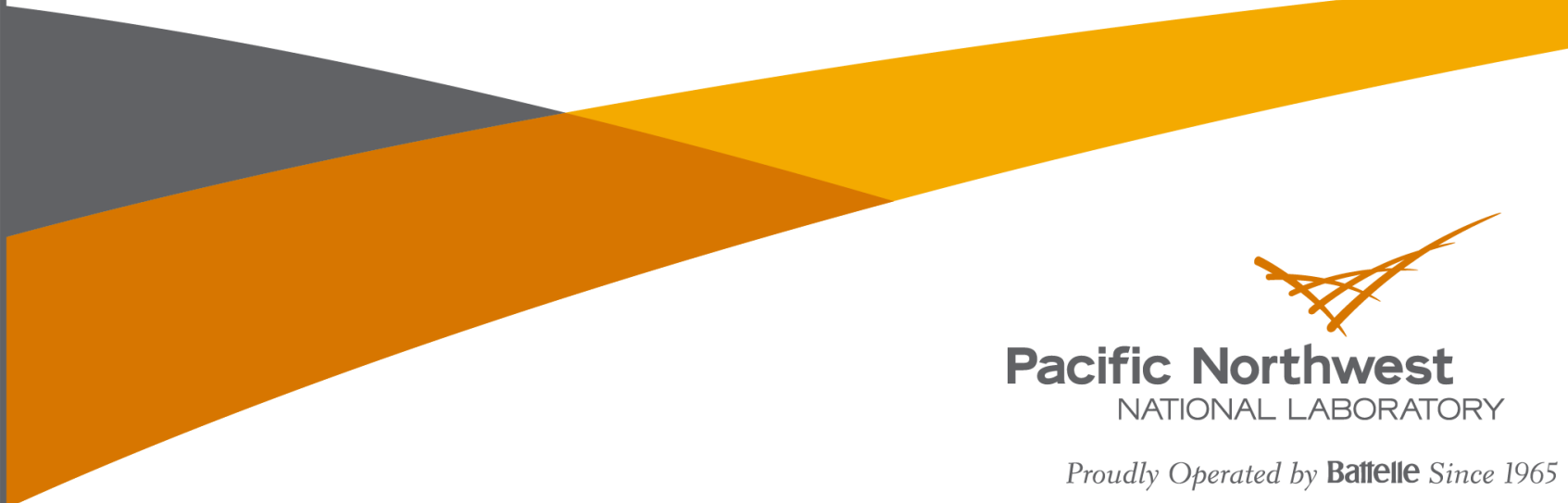




\title{
DISCLAIMER
}

This report was prepared as an account of work sponsored by an agency of the United States Government. Neither the United States Government nor any agency thereof, nor Battelle Memorial Institute, nor any of their employees, makes any warranty, express or implied, or assumes any legal liability or responsibility for the accuracy, completeness, or usefulness of any information, apparatus, product, or process disclosed, or represents that its use would not infringe privately owned rights. Reference herein to any specific commercial product, process, or service by trade name, trademark, manufacturer, or otherwise does not necessarily constitute or imply its endorsement, recommendation, or favoring by the United States Government or any agency thereof, or Battelle Memorial Institute. The views and opinions of authors expressed herein do not necessarily state or reflect those of the United States Government or any agency thereof.

\author{
PACIFIC NORTHWEST NATIONAL LABORATORY \\ operated by \\ BATTELLE \\ for the \\ UNITED STATES DEPARTMENT OF ENERGY \\ under Contract DE-AC05-76RL01830
}

Printed in the United States of America
Available to DOE and DOE contractors from the Office of Scientific and Technical Information, P.O. Box 62, Oak Ridge, TN 37831-0062; ph: (865) 576-8401 fax: $(865) 576-5728$
email: reports $a$ adonis.osti.gov
Available to the public from the National Technical Information Service 5301 Shawnee Rd., Alexandria, VA 22312 ph: (800) 553-NTIS (6847) email: orders@ntis.gov <http://www.ntis.gov/about/form.aspx> Online ordering: http://www.ntis.gov




\title{
GIS Framework for Large River Geomorphic Classification to Aid in the Evaluation of Flow-Ecology Relationships
}

\author{
CR Vernon \\ EV Arntzen \\ MC Richmond \\ RA McManamay ${ }^{1}$ \\ TP Hanrahan \\ CL Rakwoski
}

February 2013

Prepared for

the U.S. Department of Energy

under Contract DE-AC05-76RL01830

Pacific Northwest National Laboratory

Richland, Washington 99352

${ }^{1}$ Oak Ridge National Laboratory

Oak Ridge, Tennessee 37831 



\begin{abstract}
Providing a means to quantitatively define flow-ecology relationships is integral in establishing flow regimes that are mutually beneficial to power production and ecological needs. This paper presents a geographic information system (GIS) framework for large river geomorphic classification that is flexible, accurate, and easily integrated with Ecological Limits of Hydrologic Alteration (ELOHA) initiatives. A case study was conducted integrating the base geomorphic aspect of this framework with the Modular Aquatic Simulation System two-dimensional (MASS2) hydraulic model and field collected data to establish optimal juvenile salmonid rearing habitat under varying flow regimes throughout an impounded portion of the lower Snake River, USA. Defining regions of optimal juvenile salmonid habitat at varying flows was used to distinguish areas that have a high potential for the creation of additional shallow water habitat. Findings indicated that the potential to create additional shallow water habitat does exist for juvenile salmonid rearing regardless of the flow scenario (discharge exceedence levels of 1, 25, 50, 75, and 99 percent) for the sample time frame (May - June 2011). The left-bank habitat of the lower Snake River was also found to be preferable for juvenile salmon rearing compared to right-bank habitat. The results from the case study suggest that the GIS framework is a capable tool when used to diagnose flow-ecology relationships. Additionally, an alternative hydrologic classification system is explored that couples well with the geographically independent nature of this GIS framework. Future applications of this framework are to utilize it in other large river systems throughout the contiguous United States. The framework also allows for the organization of large river data to be quickly accessed and used for multi-river comparison and analysis. Future development of a backend database within an interactive web platform would be highly beneficial to create a readily available and standardized mechanism to facilitate classification efforts conducted at the national scale.
\end{abstract}




\section{Acknowledgments}

Mark Bevelhimer (Oak Ridge National Laboratory) and Geoff McMichael (Pacific Northwest National Laboratory) provided guidance and advice through all phases of the project. This project was supported by the U.S. Department of Energy, Office of Energy Efficiency and Renewable Energy - Wind and Water Power Program. 


\section{Acronyms and Abbreviations}

$\begin{array}{ll}\text { ABBREV } & \text { DEFINITION } \\ \text { cfs } & \text { cubic feet per second } \\ \text { DEM } & \text { Digital Elevation Model } \\ \text { ELOHA } & \text { Ecological Limits of Hydrologic Alteration } \\ \text { GIS } & \text { Geographic Information System } \\ \text { LB } & \text { left-bank } \\ \text { MASS2 } & \text { Modular Aquatic Simulation System two-dimensional } \\ \text { NAIP } & \text { National Agriculture Imagery Program } \\ \text { NHDPlusV2 } & \text { National Hydrography Dataset Plus Version 2 } \\ \text { RB } & \text { right-bank }\end{array}$





\section{Contents}

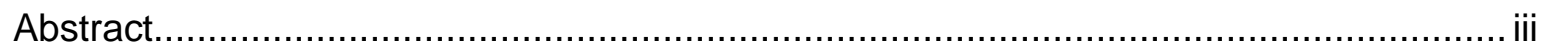

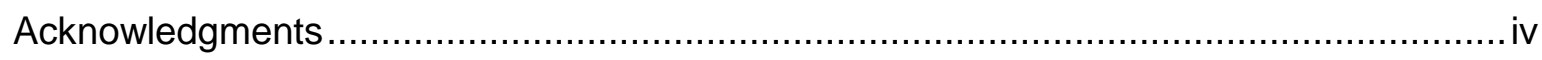

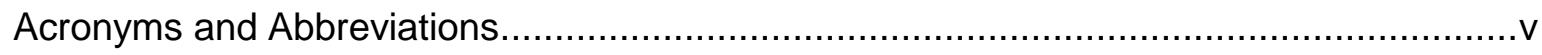

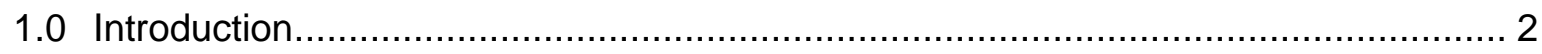

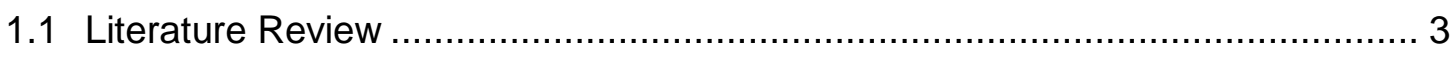

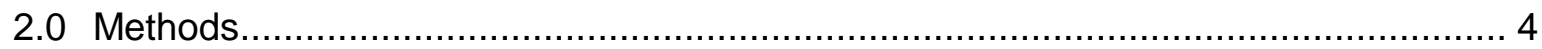

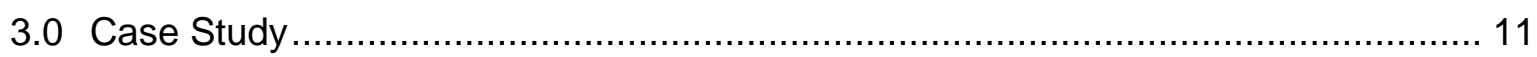

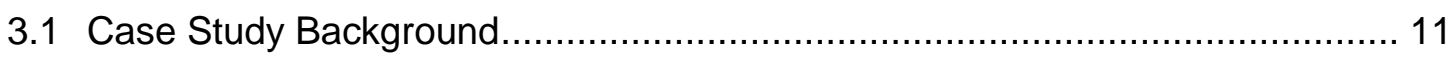

3.2 Case Study Methods ................................................................... 11

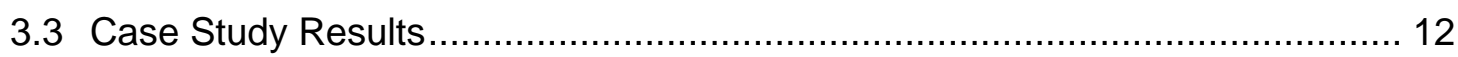

3.4 Case Study Discussion and Conclusions ............................................... 24

4.0 Alternative Hydrologic Classification Coupling ............................................ 24

4.1 Hydrologic Classification Rationale .................................................... 24

4.2 US Hydrologic Classification and Predictive Models ..................................... 25

4.3 Application of Hydrologic Classification in Determining Environmental Flows ... 25

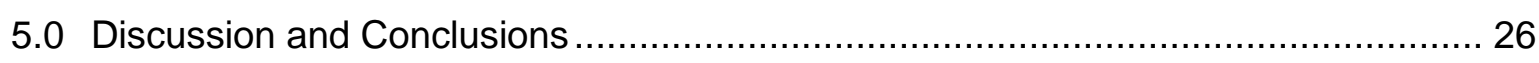

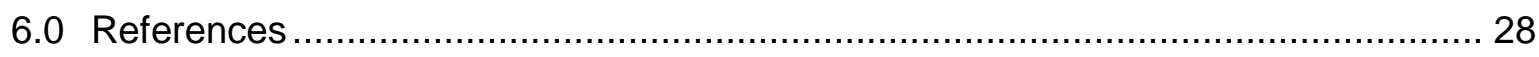




\section{Figures}

Figure 1. Site map of the hydroelectric dams and field sample locations along the lower Snake River, USA.

Figure 2. An example address location points generated from a smoothed NHDPlusV2 flowline route. The area shown is Chief Timothy State Park, Clarkston, WA

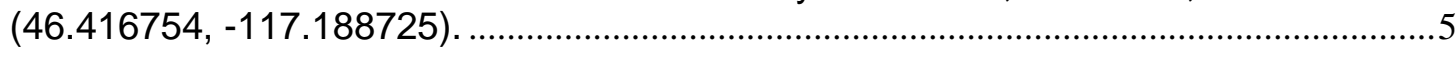

Figure 3. Valley floor polygon delineation. ......................................................................

Figure 4. Active channel transects for each address location................................................

Figure 5. Address location transects intersecting islands within the active channel. ..........9

Figure 6. Base geomorphic aspect of the framework showing similitude in complexity along the Snake River, USA ................................................................................ 10

Figure 7. Left-bank flow scenario for a one percent exceedence level. .................................13

Figure 8. Left-bank flow scenario for a 25 percent exceedence level. ..................................14

Figure 9. Left-bank flow scenario for a 50 percent exceedence level. ................................15

Figure 10. Left-bank flow scenario for a 75 percent exceedence level. ................................16

Figure 11. Left-bank flow scenario for a 99 percent exceedence level. ...............................17

Figure 12. Right-bank flow scenario for a one percent exceedence level. ...........................18

Figure 13. Right-bank flow scenario for a 25 percent exceedence level..............................19

Figure 14. Right-bank flow scenario for a 50 percent exceedence level...............................20

Figure 15. Right-bank flow scenario for a 75 percent exceedence level..............................21

Figure 16. Right-bank flow scenario for a 99 percent exceedence level..............................22 


\section{Tables}

Table 1. Frequency of class occurrence and where the class ranks in terms of similarity. 23 Table 2. Mean, standard deviation, and left-bank (LB) to right-bank (RB) differences for

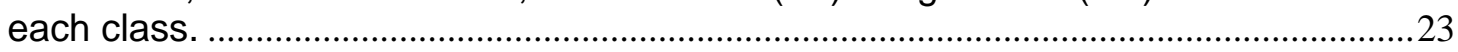

Table 3. Sum of frequencies for each flow scenario. ..........................................................24 


\subsection{Introduction}

Assessing the environmental benefits of proposed flow modifications to large rivers provides invaluable insight into future hydropower project operations and relicensing activities. Providing a means to quantitatively define flow-ecology relationships is integral in establishing flow regimes that are mutually beneficial to power production and ecological needs. To compliment this effort an opportunity to create versatile tools that can be applied to broad geographic areas has been presented. In particular, integration with efforts standardized within the ecological limits of hydrologic alteration (ELOHA) is highly advantageous (Poff et al. 2010). This paper presents a geographic information system (GIS) framework for large river classification that houses a base geomorphic classification that is both flexible and accurate, allowing for full integration with other hydrologic and hydraulic models focused on addressing ELOHA efforts.

The GIS framework is demonstrated through a case study that integrates publically available National Hydrography Dataset Plus Version 2 (NHDPlusV2) data, Modular Aquatic Simulation System two-dimensional (MASS2) hydraulic model data, and field collected data into the framework to produce a suite of flow-ecology related outputs. The case study objective was to establish areas of optimal juvenile salmonid rearing habitat under varying flow regimes throughout an impounded portion of the lower Snake River, USA (Figure 1) as an indicator to determine sites where the potential exists to create additional shallow water habitat.

Additionally, an alternative hydrologic classification useable throughout the contiguous United States which can be coupled with the geomorphic aspect of this framework is also presented. This framework provides the user with the ability to integrate hydrologic and ecologic data into the base geomorphic aspect of this framework within a geographic information system (GIS) to output spatiotemporally variable flow-ecology relationship scenarios. 


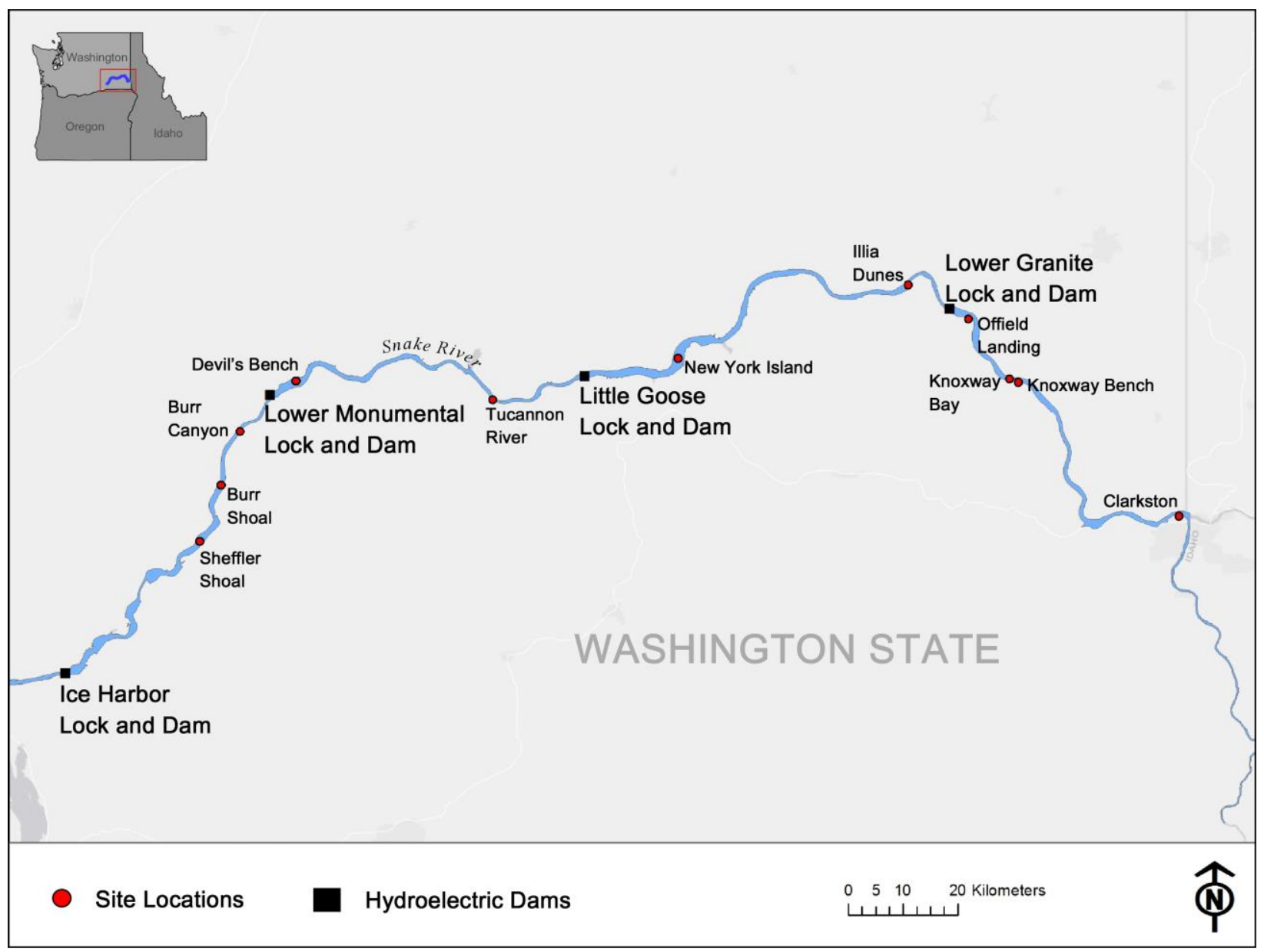

Figure 1. Site map of the hydroelectric dams and field sample locations along the lower Snake River, USA.

\subsection{Literature Review}

The majority of literature considered in this research was limited to methods that focused on large river classification systems where impoundments were present. Seminal works that heavily influenced the selected literature were also reviewed. The general trend in the literature specified most classification methodologies as either hierarchical or based on various types of statistical clustering. Among the more complex studies were those that sought to classify rivers while considering spatio-temporal variation. Studies that addressed data accessibility and the use of current GIS data were also reviewed.

Hierarchical classification models are based on the principle that watershed-scale physical characteristics provide the template and constraints within which point-scale characteristics develop. Foundational work contributed by Kellerhals, Church, and Bray (1976) and Frissell et al. (1986) focus on creating a systematic approach to understanding diversity and variability in stream systems and their surrounding watersheds. Rosgen (1996) also introduced a fundamental stream classification system that provides diagnostics for stream type at three different levels that consider a variety of stream characteristics such as valley morphology, 
channel form, cross-sectional attributes, and others. Modern variations on the principles presented in these three works are found throughout the literature.

Other hierarchical approaches, such as Brierley and Fryirs (2000), use a classification method based on the concept of "river styles," account for certain gaps in Rosgen's (1996) framework by explaining river behavior and placing it in a spatio-temporal context. The inclusion of varying spatiotemporal scales within a classification system provides the user with the capability to account for the full scope of flow-ecology relationships within a study area (Brandt 2000; Rowntree and Wadeson 1998). Approaches to capture spatiotemporal variation in rivers can also be seen in studies that attempt to classify catchments under varying hydrologic periods as a means to provide predictions to determine how environmental impacts in one system could influence another similar system (Wagener et al. 2007; Snelder, Biggs, and Weatherhead 2004; Reidy Liermann et al. 2011).

Another prominent classification technique is to develop classes based upon statistical similarity in a process called clustering. Clustering is often a function of adjacency and other affinity variables (Brenden et al. 2008). Clustering can be applied to classifications of both large and small spatial scales. For instance, Hersh and Maidment (2007) developed a cluster-based stream classification system for the state of Texas, USA that was a direct response to the need to determine environmental flow requirements. Jacobson, Elliot, and Huhmann (2010) used multivariate statistical clustering to create a multi-scale river classification that could take the potential effects of dams, significant tributaries, and other channel constraints into consideration when classifying both segments and reaches of the Missouri River, USA.

Many studies have taken advantage of the capability of a GIS to spatially organize and find similarity in data for use in river classification (Dauble et al. 2003; Hersh and Maidment 2007; Higgins et al. 2005; Jacobson, Elliot, and Huhmann 2010; Snelder, Biggs, and Weatherhead 2004; Wang et al. 2011; Whited, Stanford, and Kimball 2002). The integration of readily available, current GIS data is vital to the success of any newer GIS river classification approach that is to be spatially transferable. The incorporation of NHDPlus data in river classification methodologies has proven to be valuable and effective (Hersh and Maidment 2007, NHDPlus Version 2, 2012). Other ancillary data provided by remote sensing analysis within a GIS also can potentially produce useable data for an otherwise data-poor region (Whited, Stanford, and Kimball 2002; Wyrick and Klingeman 2011).

\subsection{Methods}

After conducting a literature review of available river classification methods generally for large rivers, the methods described in this chapter were developed to enable the user to have access to a framework that would be flexible, repeatable, and accurate. The basis of this approach was derived from a river addressing system conceived by Elliott and Jacobson (2006) that used defined metrics at prescribed locations along a river that both describe the locations and are used as a means of comparison for areas that have similar traits. 
NHDPlusV2 data were used to provide a platform by which any user can access the base data required to create the geomorphic aspect of this framework. NHDPlusV2 data is also one of the most up-to-date open-source GIS resources and is maintained for easy download. The base geomorphic aspect of the framework utilizes waterbody, river area, river flowlines, and the National Elevation Dataset (NED) 10-meter Digital Elevation Model (DEM) housed within the NHDPlusV2 archive.

The addressing system houses points that are evenly distributed along a river route (

Figure 2). Point spacing was chosen to be close enough to capture smaller variation within a specified reach as well as encompass the entire study area through aggregation. The address locations were derived from the NHDPlusV2 flowline data for the intended river. Flowlines contain attributes that show the direction of flow and are derived from elevation models (McKay et al. 2012). Smoothing was applied to the flowline to ensure that the sinuosity of the river was accurately captured. The smoothed flowline was then validated by visually comparing the planform to National Agriculture Imagery Program (NAIP) aerial imagery (National Agriculture Imagery Program 2012). A route was then created from the flowline to permit linear referencing. Hatches, or markers along a line at a defined interval, as points and transecting lines perpendicular to the flowline were then created and extracted from the route (Figures 2 and 4). The following four metrics were considered to define the geomorphic characteristics needed to create a base framework: valley floor width, active channel width, river sinuosity, and a braiding index. Each metric was then calculated and added as an attribute for each address location point.

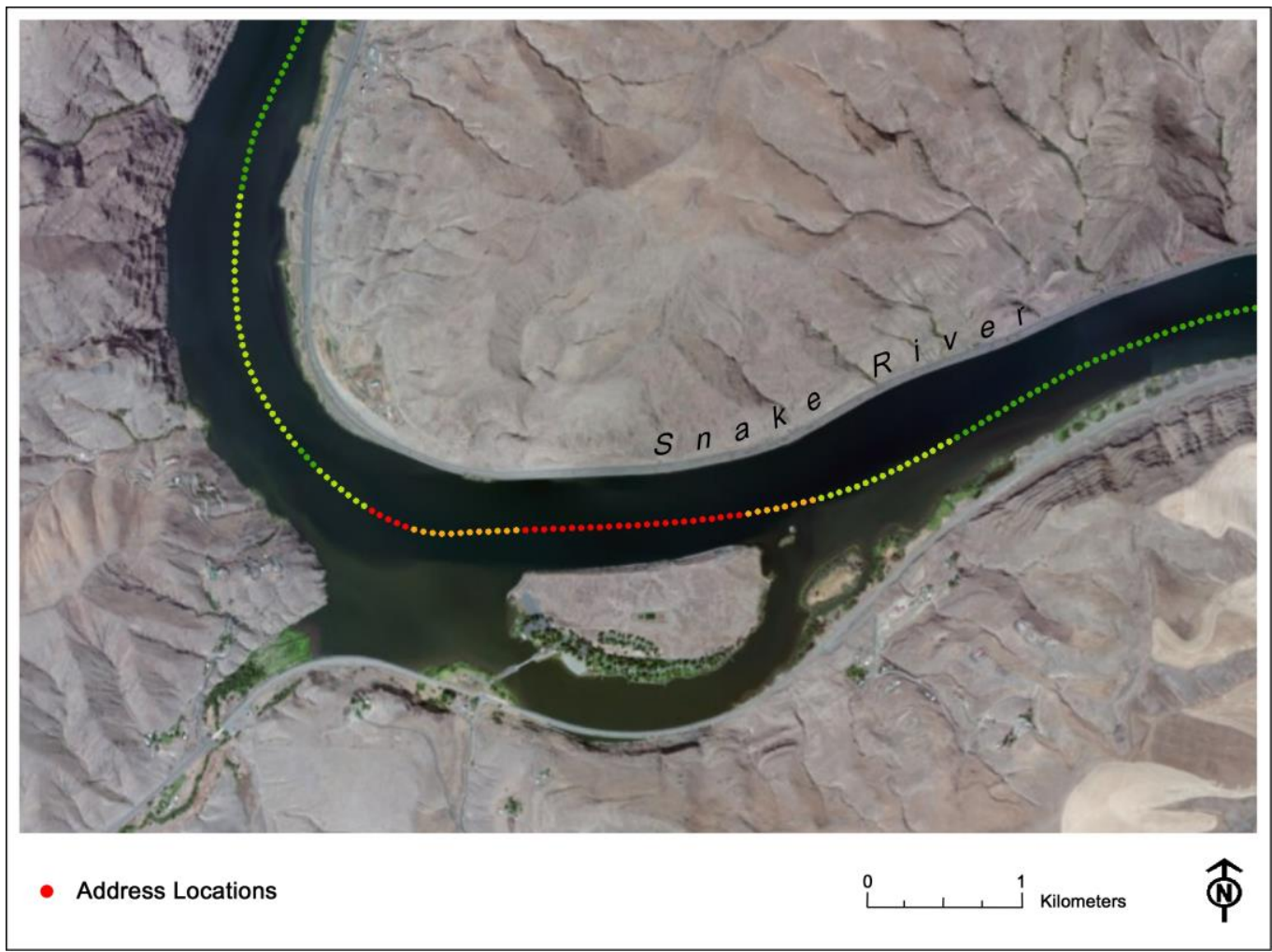


Figure 2. An example address location points generated from a smoothed NHDPlusV2 flowline route. The area shown is Chief Timothy State Park, Clarkston, WA (46.416754, -117.188725).

Valley floor width was delineated from the NED 10-meter DEM. This was completed by digitizing the border of the valley floor encompassing the channel (Figure 3). Alternatively, an object-oriented feature classification software, such as Overwatch's Feature Analyst, could be set up to automate the delineation of the valley floor (Overwatch Systems 2012). Transects for each address location were clipped to the valley floor width polygon and each width was joined to the address location points. Active channel width measurements were taken from the NHDPlusV2 river area and waterbody data. The address location transects were clipped to the river area polygon and their measurements determined and transferred to the address location points (Figure 4). Sinuosity was calculated by determining a distance threshold around each address location by which the sinuosity would be calculated for each location. Sinuosity is relative to scale; therefore, the distance threshold may be different for each project. A braiding index representing how many channels exist within the full active channel was calculated from the NHDPlusV2 river area data. A negative of the river area polygon was created to be able to extract islands that were present in the river system. These islands were then intersected with the address location transects to create a value for the number of channels existing in the river at each address location point (Figure 5). 


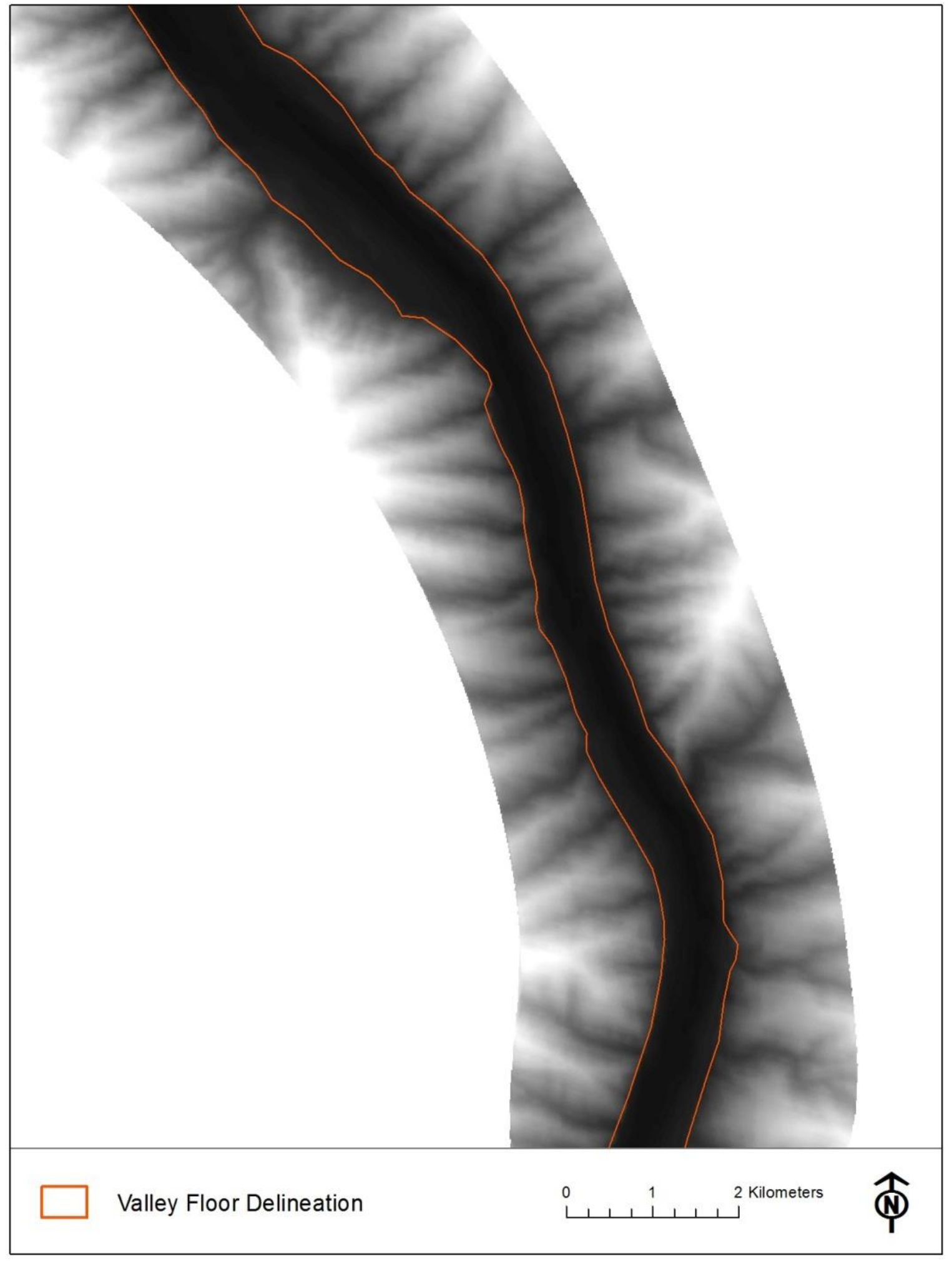

Figure 3. Valley floor polygon delineation. 


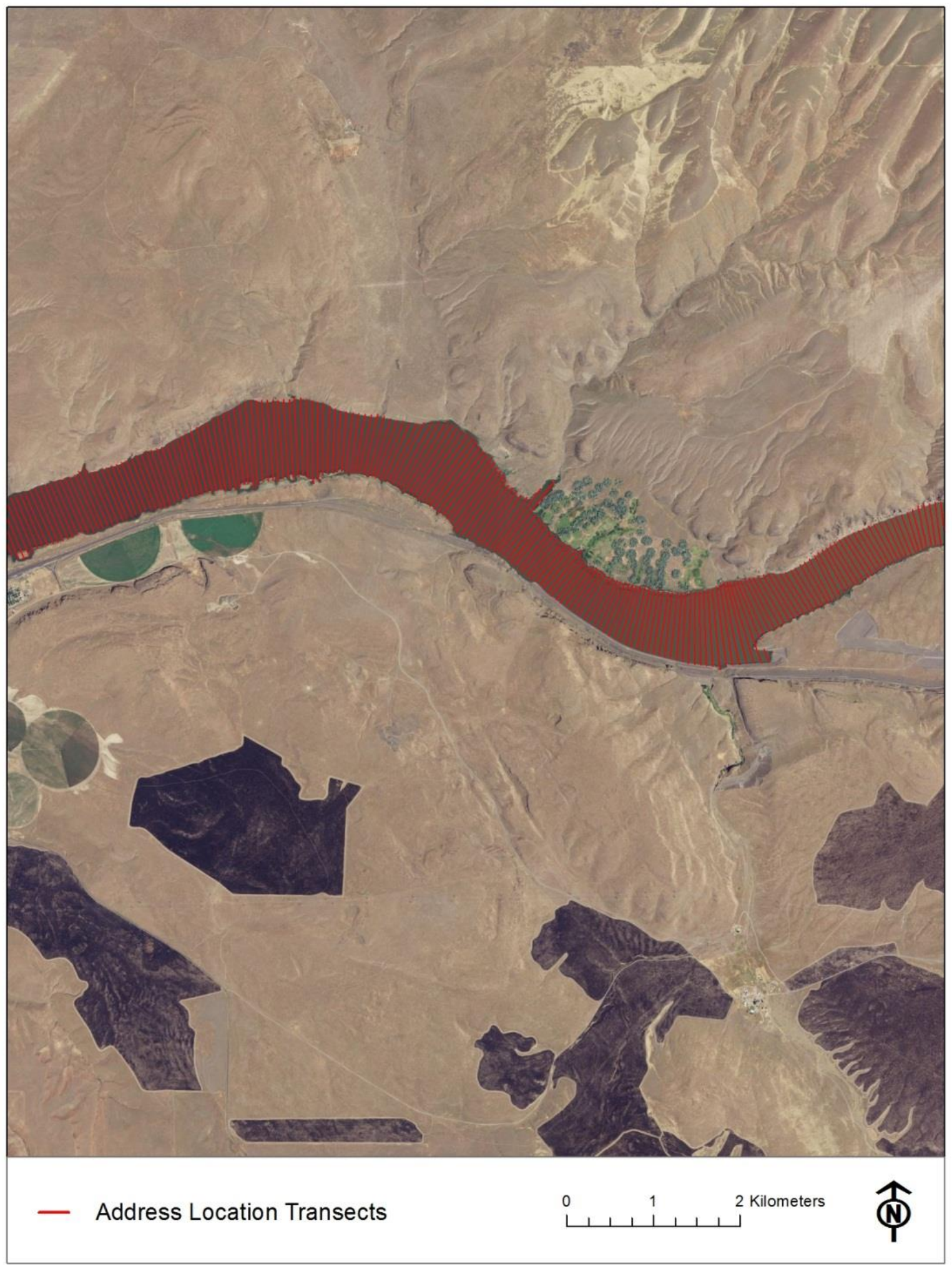

Figure 4. Active channel transects for each address location. 


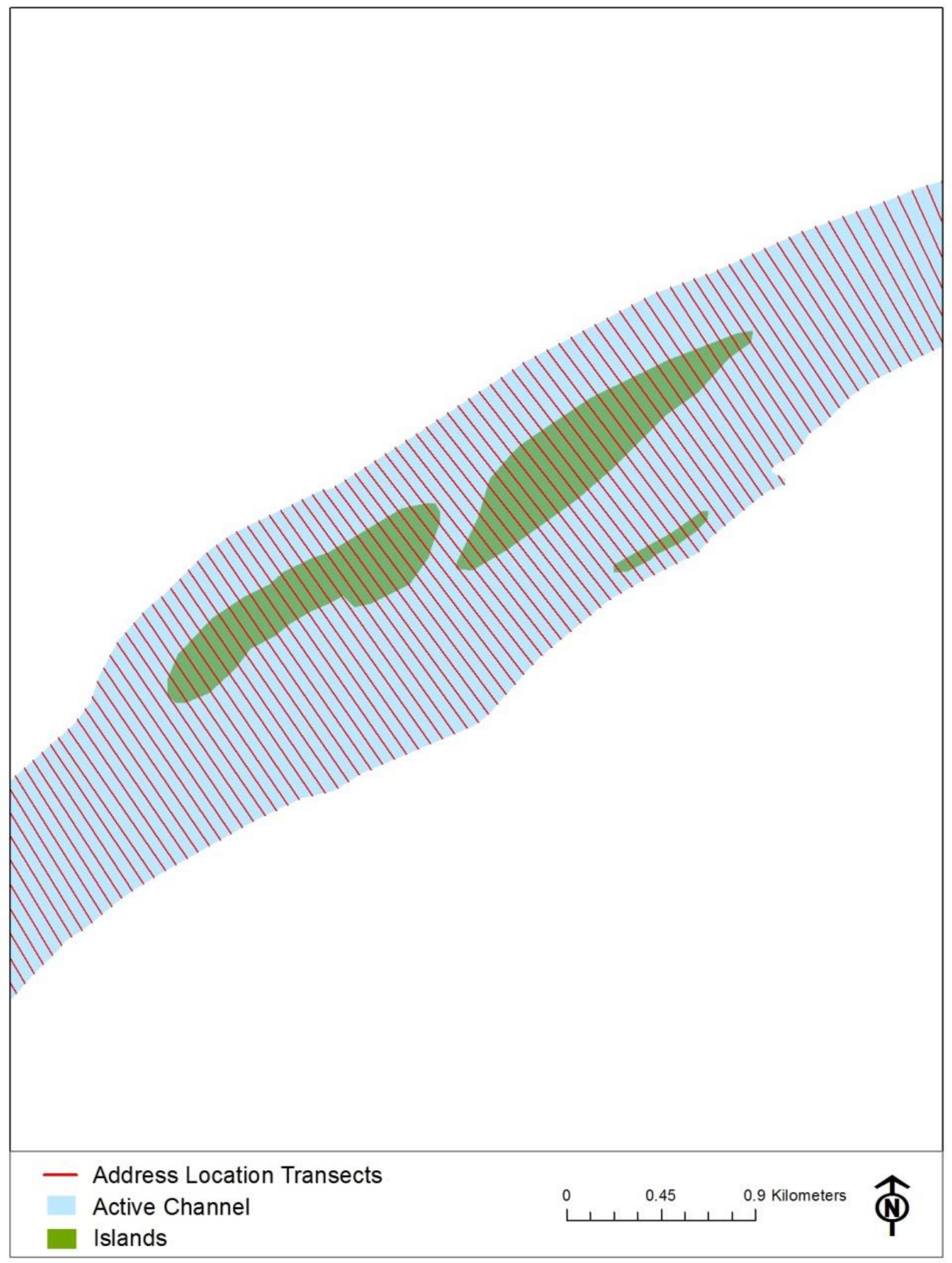

Figure 5. Address location transects intersecting islands within the active channel. 
Multiple ways of grouping or clustering the measurements are possible within this framework. Using address locations along the river that house specific metric values allow the user to either hierarchically arrange or statistically cluster the metric data producing an output that either describes the river as it relates to certain standards and other rivers or as the river is described by its own characteristics. For this work, the values for each metric were made comparable by being placed on a common scale with the intention of showing the amount of geomorphic complexity at each address location. For instance, an address location with a high value for braiding would have a larger value for complexity. Each metric was combined into either four or seven classes that represented natural statistical breaks within their respective values using Jenks optimization method (Jenks 1967). Often a user will need to classify a river system at different scales representing generalization or increased specificity. The number of classes in this framework can be adjusted to represent multiple spatial scales to properly describe or compare an intended study area. Based on the metric class outputs, a final representation for complexity at each address location was then calculated by weighting each class value for each metric based upon the metrics influence upon the overall study area. The outputs were then displayed in a GIS to show the similar and dissimilar river complexity based on geomorphic attributes (Figure 6).

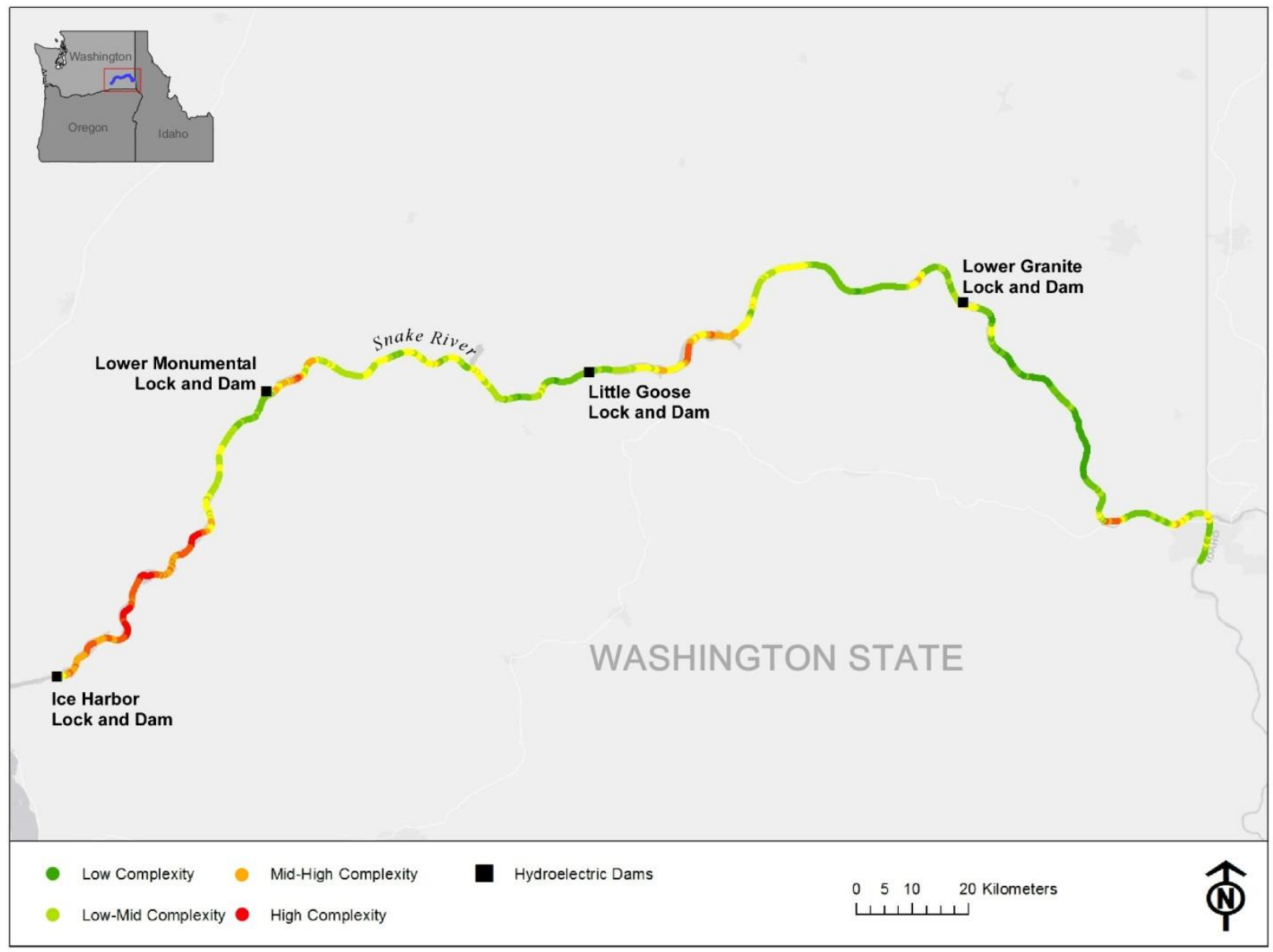

Figure 6. Base geomorphic aspect of the framework showing similitude in complexity along the Snake River, USA. 


\subsection{Case Study}

\subsection{Case Study Background}

To explore the capabilities of the framework, a case study was conducted that coupled the output of a hydraulic model with the base geomorphic aspect of the framework. The framework was coupled with the two-dimensional MASS2 hydraulic model (Richmond, et al 1999; Perkins and Richmond 2007; Rakowski, et al 2010) to output a series of flow scenarios to determine optimal locations where habitat augmentation could benefit rearing salmonids when subjected to a varying flow regime. Data that were previously collected by Arntzen et al. (2012) were used to calibrate the classification which set a baseline for comparison. The previous data were collected in order to describe the fish community structure, habitat quality, and biological integrity of a select group of habitat complexes in the lower Snake River from fall 2010 through summer 2011.

Study locations represented areas where sediment may be removed during channel maintenance dredging operations, sites where additional shallow-water rearing habitat has previously been or could potentially be created in the future, or locations that represent reference sites where high-quality rearing habitat for juvenile Chinook salmon is thought to currently exist. The overall purpose of describing the locations was to gain a better understanding of existing high-quality shallow-water rearing habitat so that like habitat can be created using in-water disposal of upriver sediments following removal and relocation. Eleven locations from throughout the four lower Snake River reservoirs were selected for the evaluation (Arntzen et al. 2012). Sampling locations included areas where sediment could be removed in the future (i.e., Clarkston) and where in-water disposal of dredged sediment has been previously used to create shallow-water habitat (i.e., Knoxway Bench Lower). However, the majority of the sampling locations are areas that are thought to represent existing high-quality shallow-water habitat. High quality shallow-water habitat was previously characterized as areas with low riverbed gradient, low velocity, and sandy substrates (USACE 2002). This determination was made based on research that showed subyearling Chinook salmon were consistently captured within areas that shared these characteristics on the Snake River (Bennett and Shrier 1986; Bennett et al. 1988a, 1990, 1991, 1993a, 1993b; Arntzen et al. 2012). The final flow scenarios displayed in our case study are grouped by their similarity to habitat metric values that are indicative of optimal juvenile salmonid rearing habitat based on previous salmonid habitat research.

\subsection{Case Study Methods}

Multiple hydrologic metric values were calculated for dates May through June 2011. These dates were chosen to coincide with the field data collection period when juvenile Chinook salmon were present within the system. Mean forebay elevation and mean discharge values were derived from hydroelectric dam operation data (USACE 2011) for Ice Harbor Dam, Lower Monumental Dam, Little Goose Dam, and Lower Granite Dam along the lower Snake River, USA. The values were then processed by the MASS2 hydraulic model and a series of metrics 
for several percent flow exceedence levels were output. The percent exceedence values of 1 , $25,50,75$, and 99 for river discharge were output to quantify the optimal juvenile salmonid rearing habitat at each flow scenario for the given test period. Flow scenarios were created for both the right and left bank due to the bedform morphology of the lower Snake River and the importance of depth as a driver in describing optimal juvenile salmonid rearing habitat. The right bank of the river is often confined by the valley floor wall which offers little shallow water habitat. In contrast, left bank conditions have a much lower lateral bed gradient and a substantially higher amount of depth locations conducive to optimal habitat. Isolating the bankside differences enhanced the comparability of the address locations to provide more detailed outputs.

Depth and velocity were selected for use in the classification from the suite of metrics produced by the MASS2 hydraulic model. Metric values were deemed to be optimal or not optimal based on calibration from the field data. Depth was considered optimal if the value was less than five meters (Arntzen et al. 2012). Average velocity at each address location was considered optimal for the range of 0.5 to $2.0 \mathrm{cfs}$. Lateral bed gradient was also calculated from the underlying bathymetry used by the MASS2 model and was considered optimal from five to 15 percent. Optimal average velocity and lateral bed gradient were derived from the field sites at which juvenile salmonid abundance was high during the time of sampling.

Geomorphic metrics were derived from the NHDPlusV2 data and the NED DEM data. The geomorphic metrics evaluated for each address location included: valley floor width, sinuosity, and active channel width. Optimal valley floor width was considered to be 600 to 1050 meters based on extracted values at optimal field data collection sites. Optimal values were also calculated from field data collection sites for active channel width and sinuosity at 500 to 750 meters and 1 to 1.35, respectively. Geomorphic metrics for optimal range were established by using the values from the field sites where juvenile salmonid abundance was high during the time of sampling.

Address location separation values were set at 40 meters to enable the user to interpret the classification on a fine or aggregated, coarse scale. For each address location a weighted score was created for the geomorphic and hydraulic model outputs which were combined to generate an overall score that defined each class. Class scores were based upon whether or not metric values were optimal in relation to their weight in the calculation. There were 14 final classes generated from the combination of the geomorphic and hydrologic metrics. Classes were then grouped into four descriptive elements representing the following: low similarity, lowmid similarity, mid-high similarity, or high similarity between reference field site values and observed address locations (Table 1).

\subsection{Case Study Results}

Flow scenario outputs were created for the following: left-bank at one percent exceedence (LB01, Figure 7); left-bank at 25 percent exceedence (LB25, Figure 8); left-bank at 50 percent exceedence (LB50, Figure 9); left-bank at 75 percent exceedence (LB75, Figure 10); left-bank at 99 percent exceedence (LB01, Figure 11); right-bank at one percent exceedence (RB01, Figure 12); right-bank at 25 percent exceedence (RB25, Figure 13); right-bank at 50 percent 
exceedence (RB50, Figure 14); right-bank at 75 percent exceedence (RB75, Figure 15); and right-bank at 99 percent exceedence (RB99, Figure 16). Ultimately, flow scenarios for the leftbank percent exceedence levels displayed much higher similarity to optimal juvenile salmonid rearing habitat derived from the field sites data than the right-bank scenarios (Table 2). In particular, the flow scenario for the left-bank at a 25 percent exceedence level showed a slightly higher frequency of high similarity classes than the other flow scenarios (Figure 8, Table 1). The majority of class occurrences ranked in the low-mid similarity classes for the left-bank scenarios and the low similarity classes for the right-bank flow scenarios (Table 3).

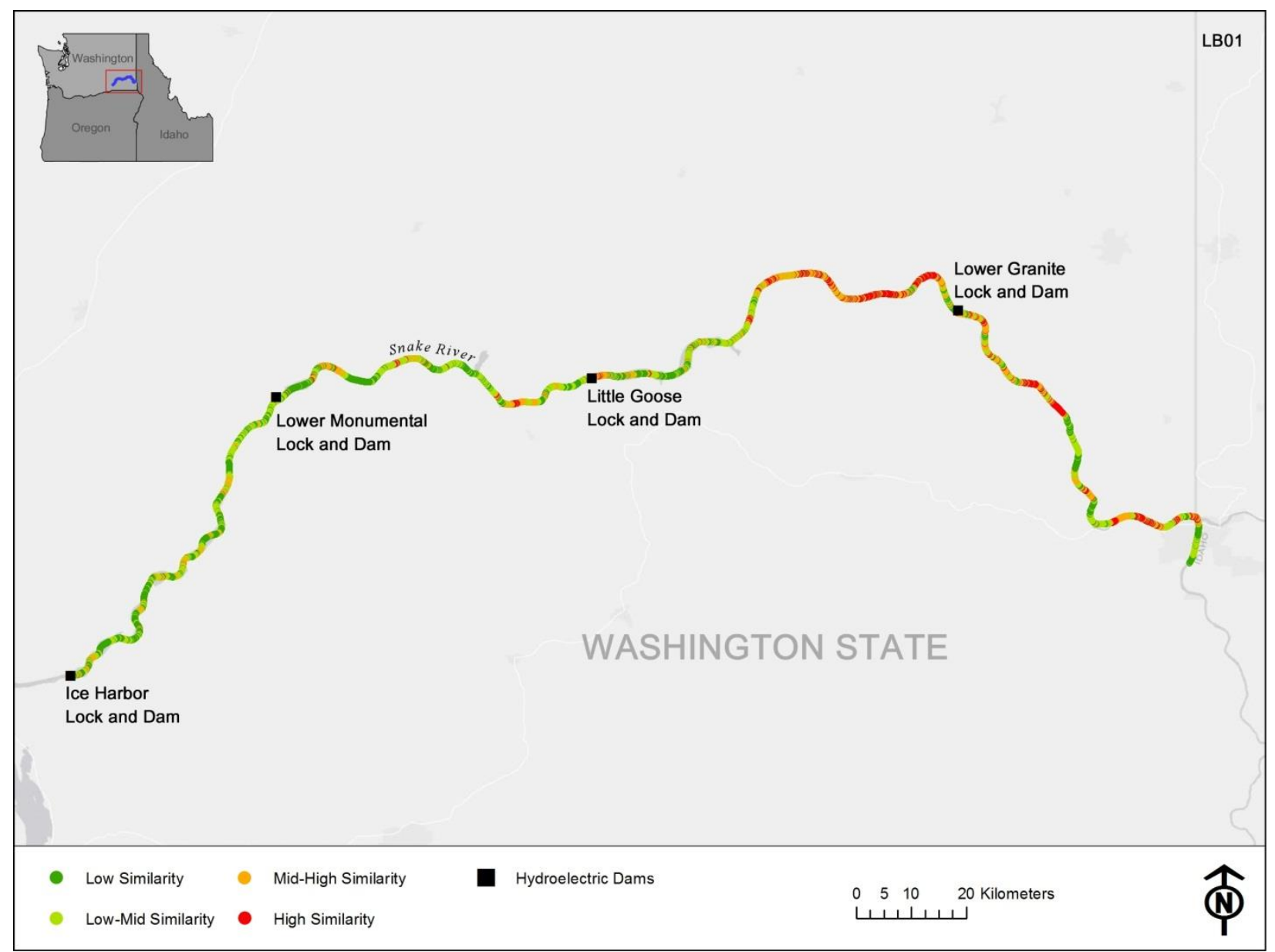

Figure 7. Left-bank flow scenario for a one percent exceedence level. 


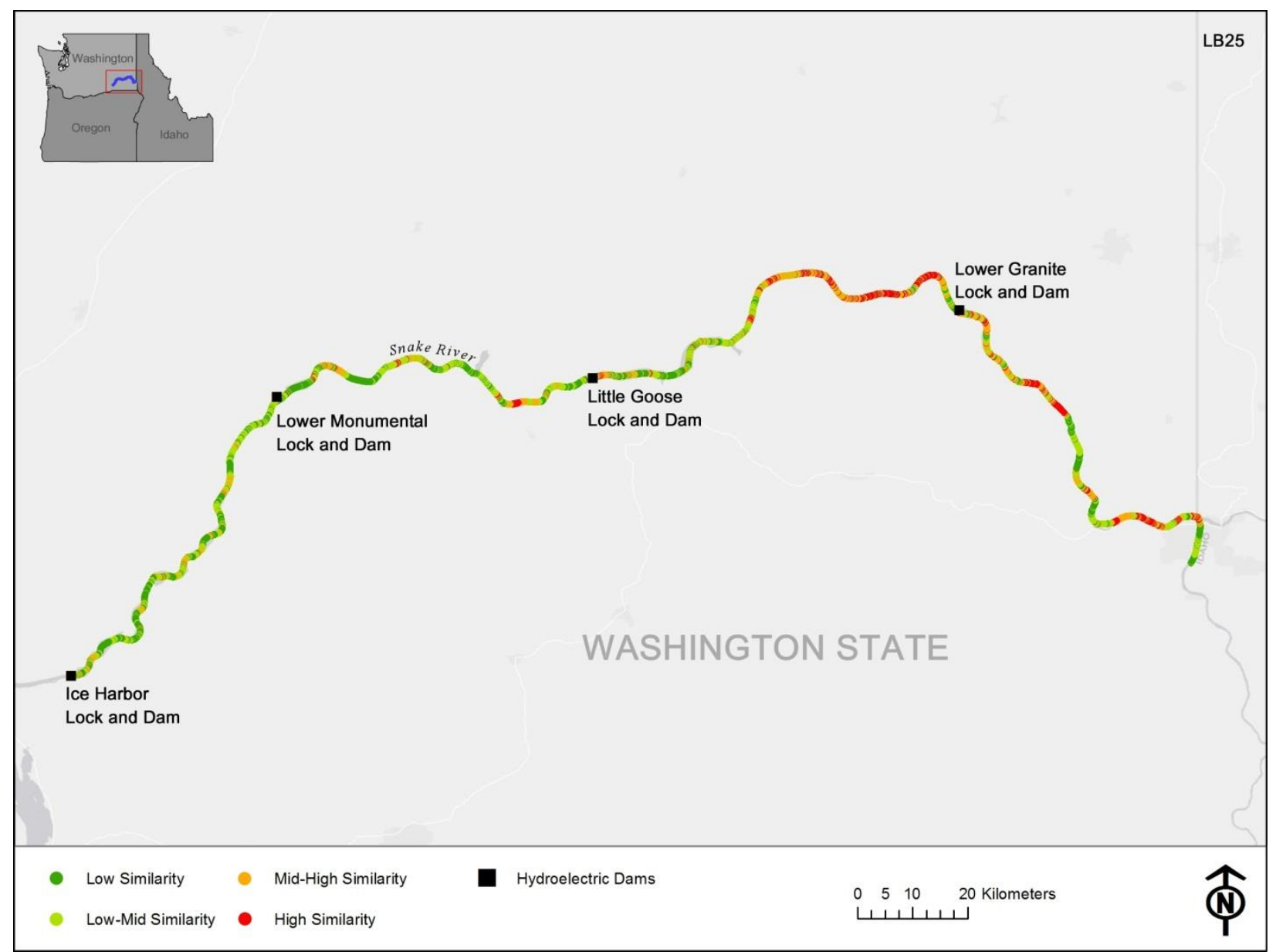

Figure 8. Left-bank flow scenario for a 25 percent exceedence level. 


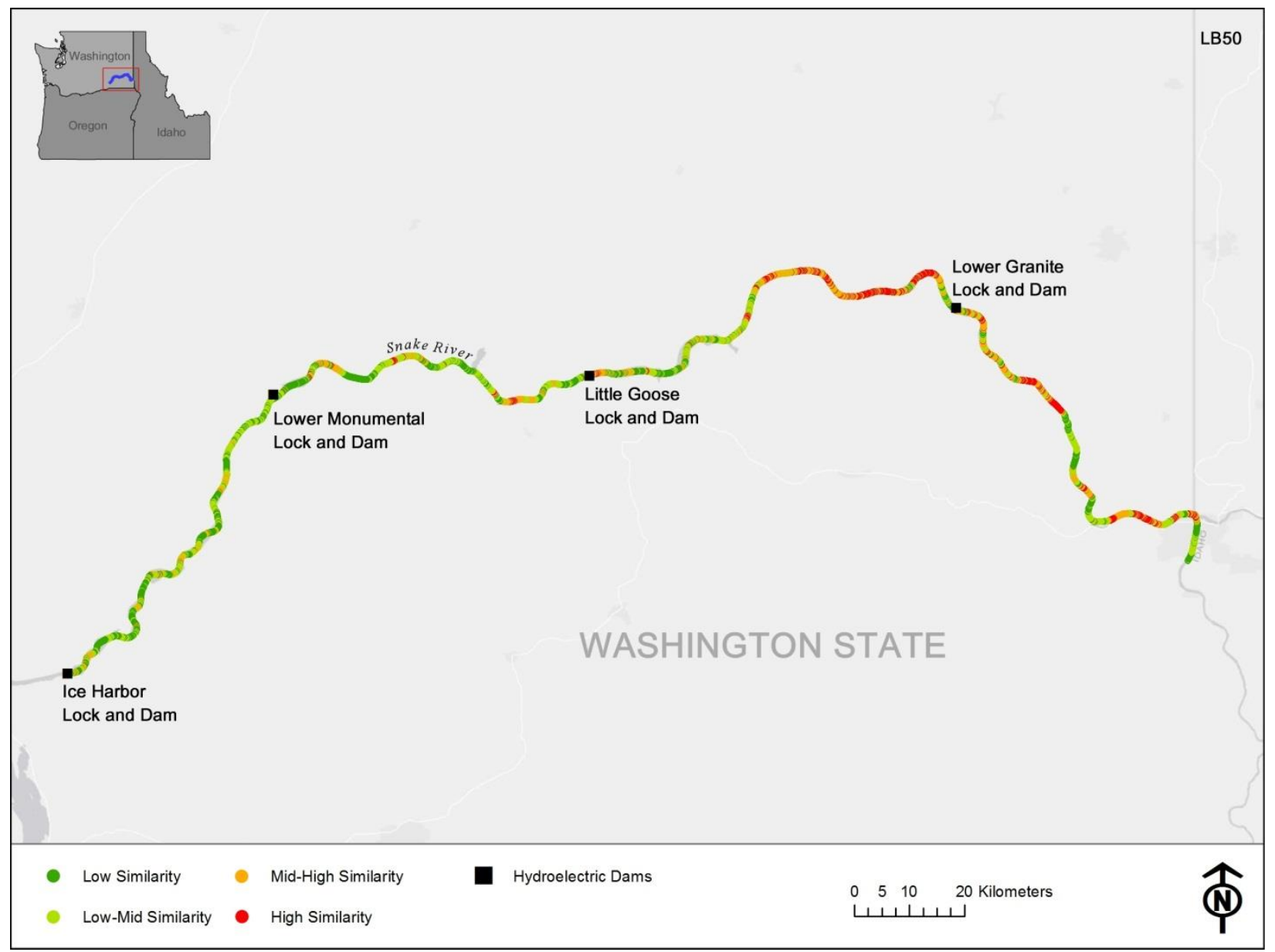

Figure 9. Left-bank flow scenario for a 50 percent exceedence level. 


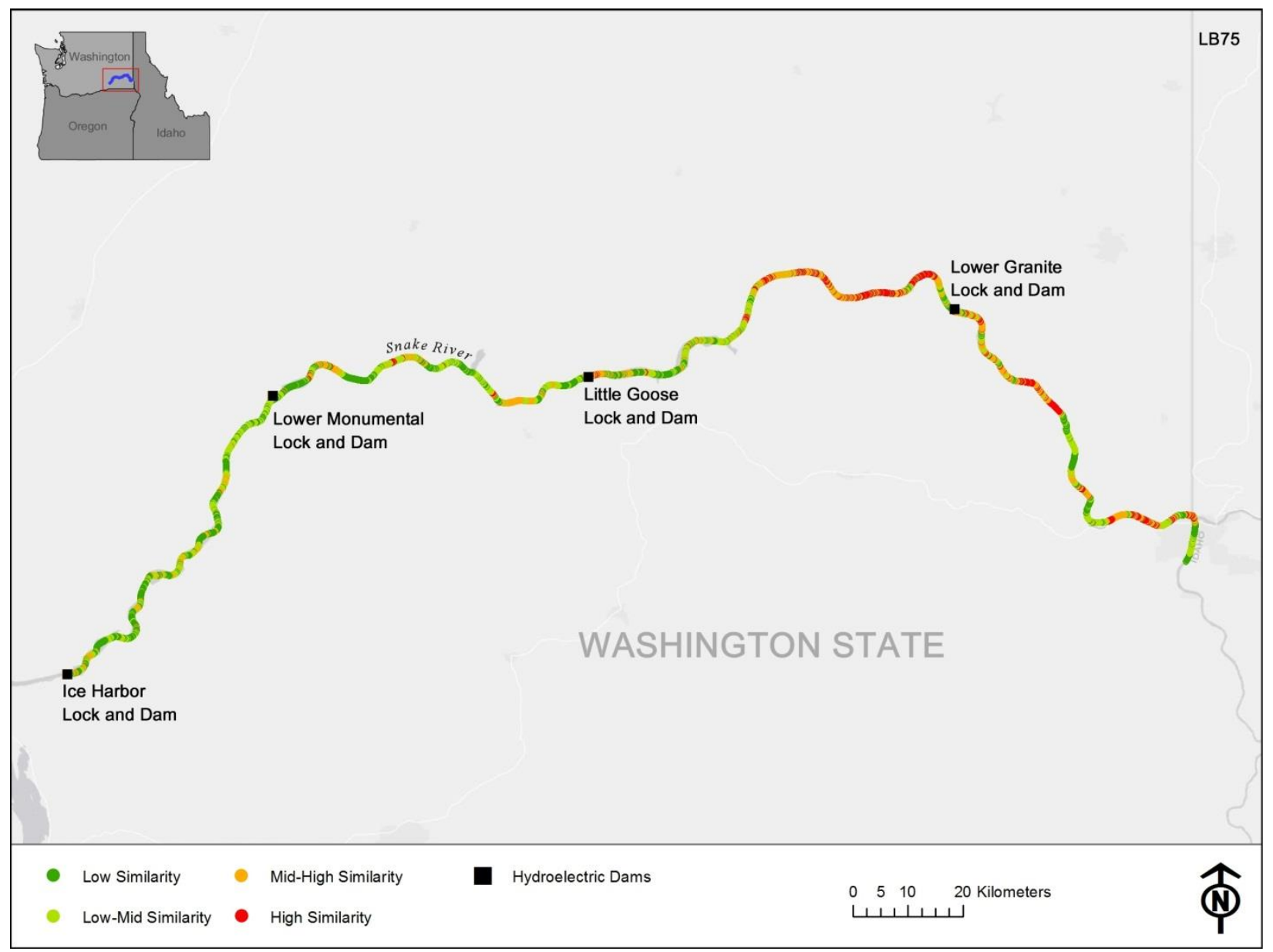

Figure 10. Left-bank flow scenario for a 75 percent exceedence level. 


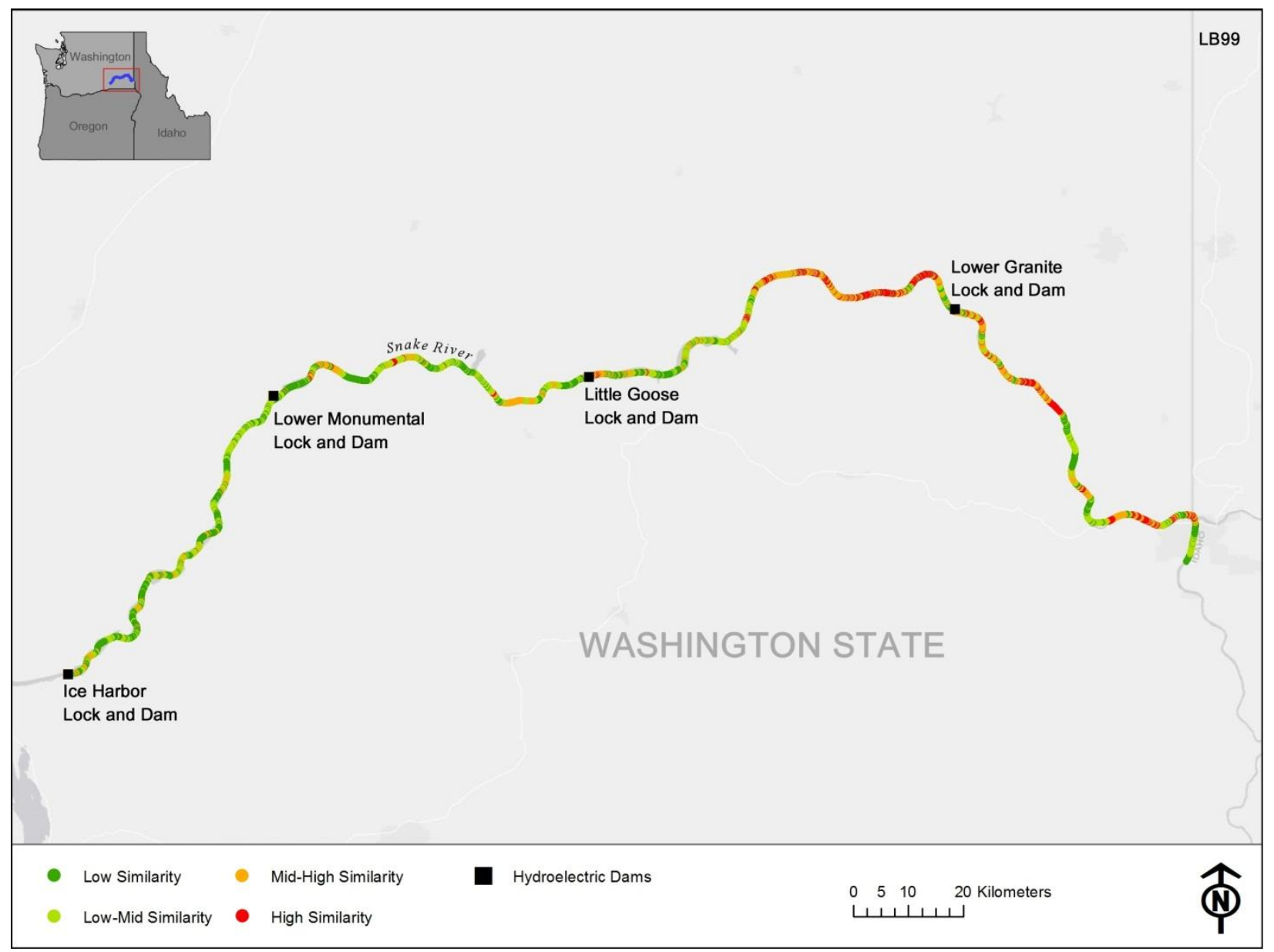

Figure 11. Left-bank flow scenario for a 99 percent exceedence level. 


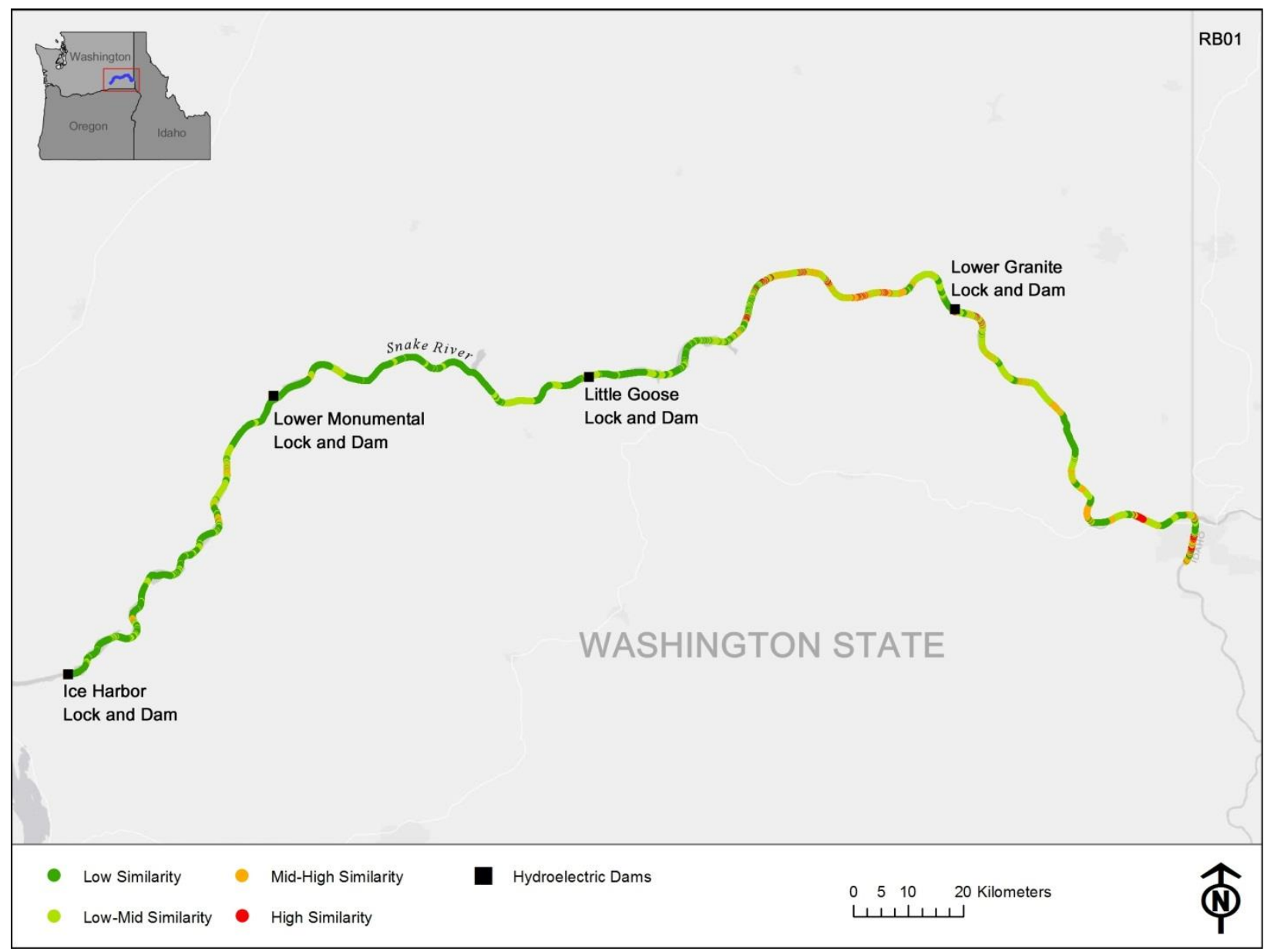

Figure 12. Right-bank flow scenario for a one percent exceedence level. 


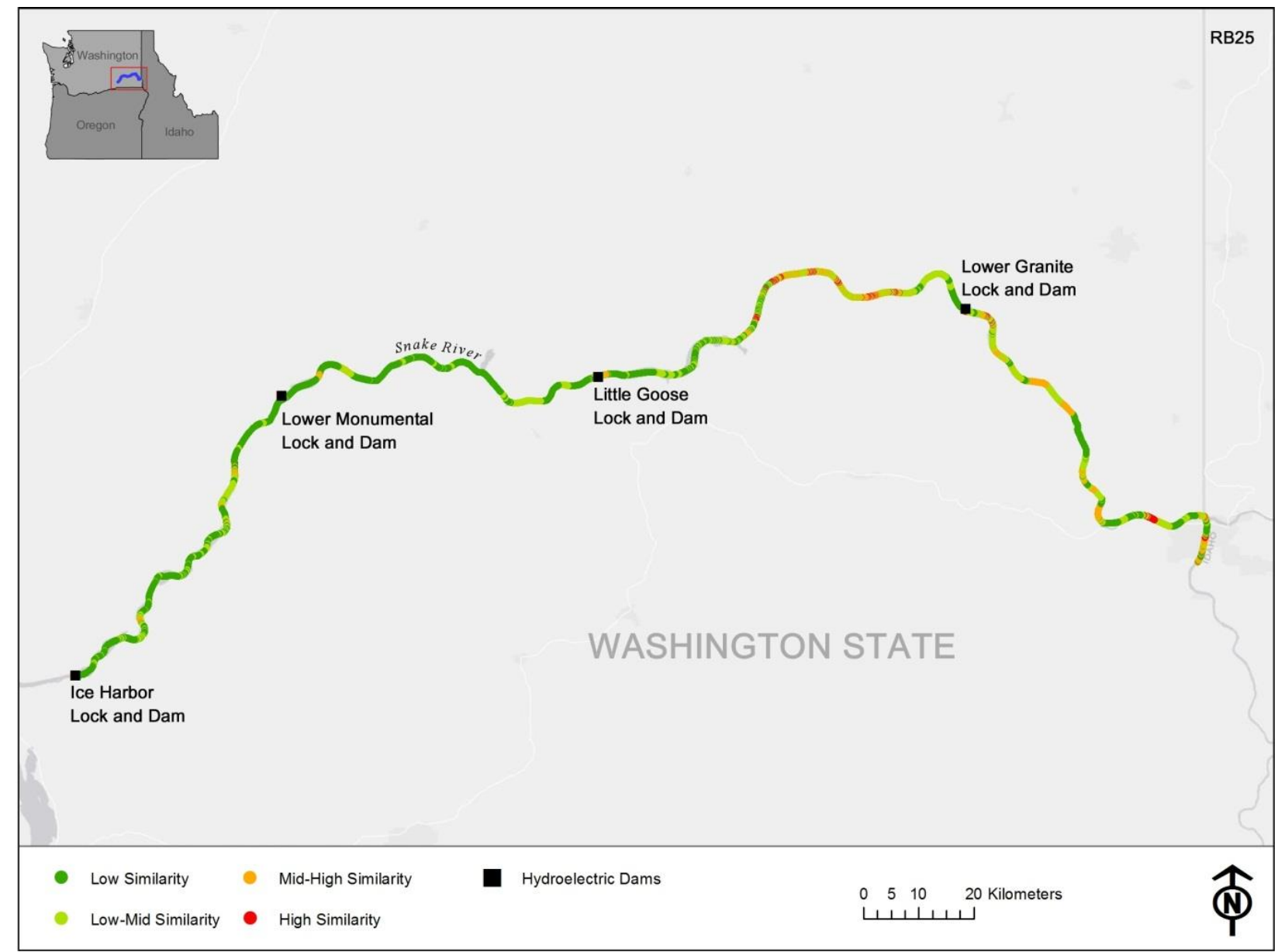

Figure 13. Right-bank flow scenario for a 25 percent exceedence level. 


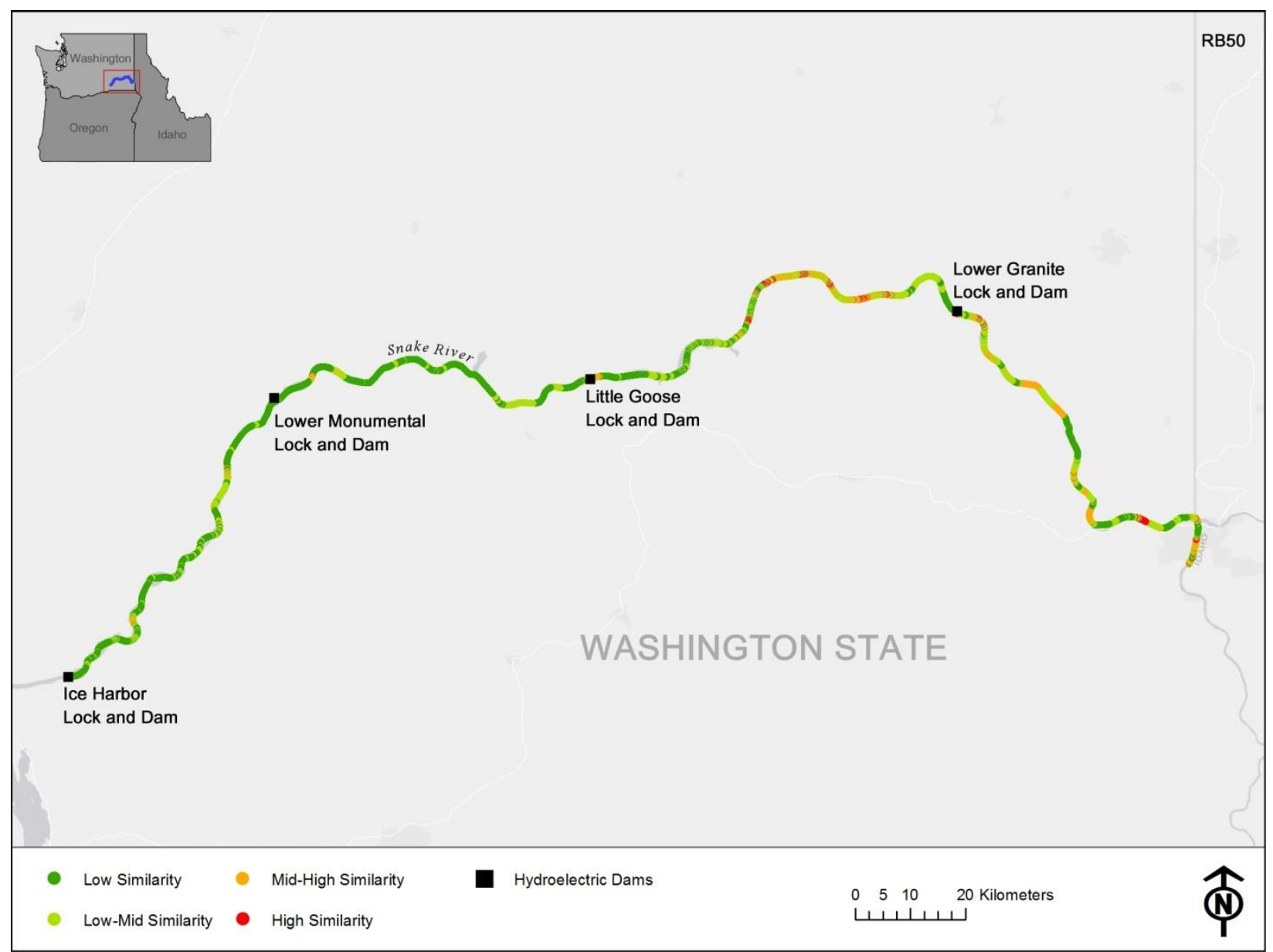

Figure 14. Right-bank flow scenario for a 50 percent exceedence level. 


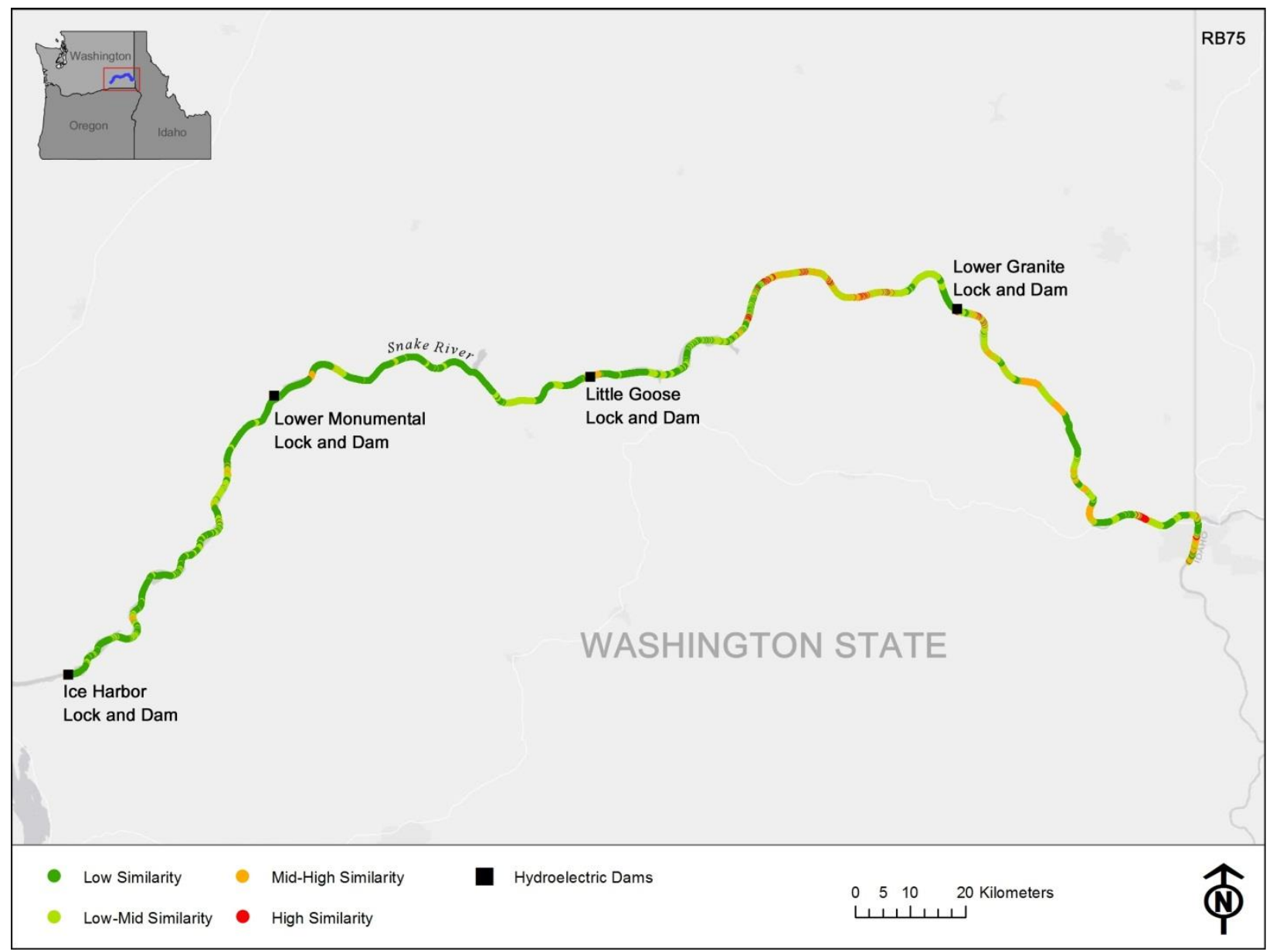

Figure 15. Right-bank flow scenario for a 75 percent exceedence level. 


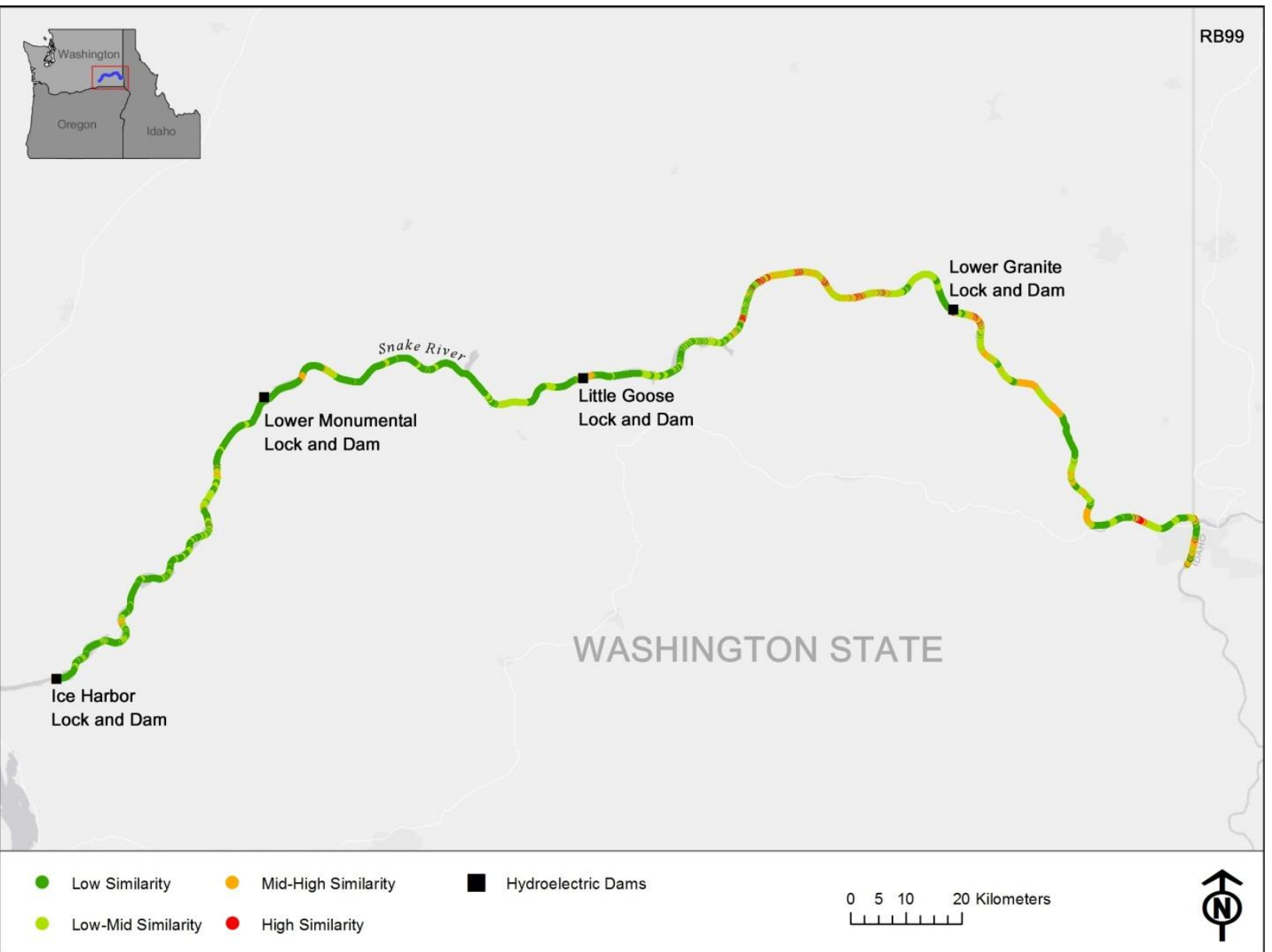

Figure 16. Right-bank flow scenario for a 99 percent exceedence level. 


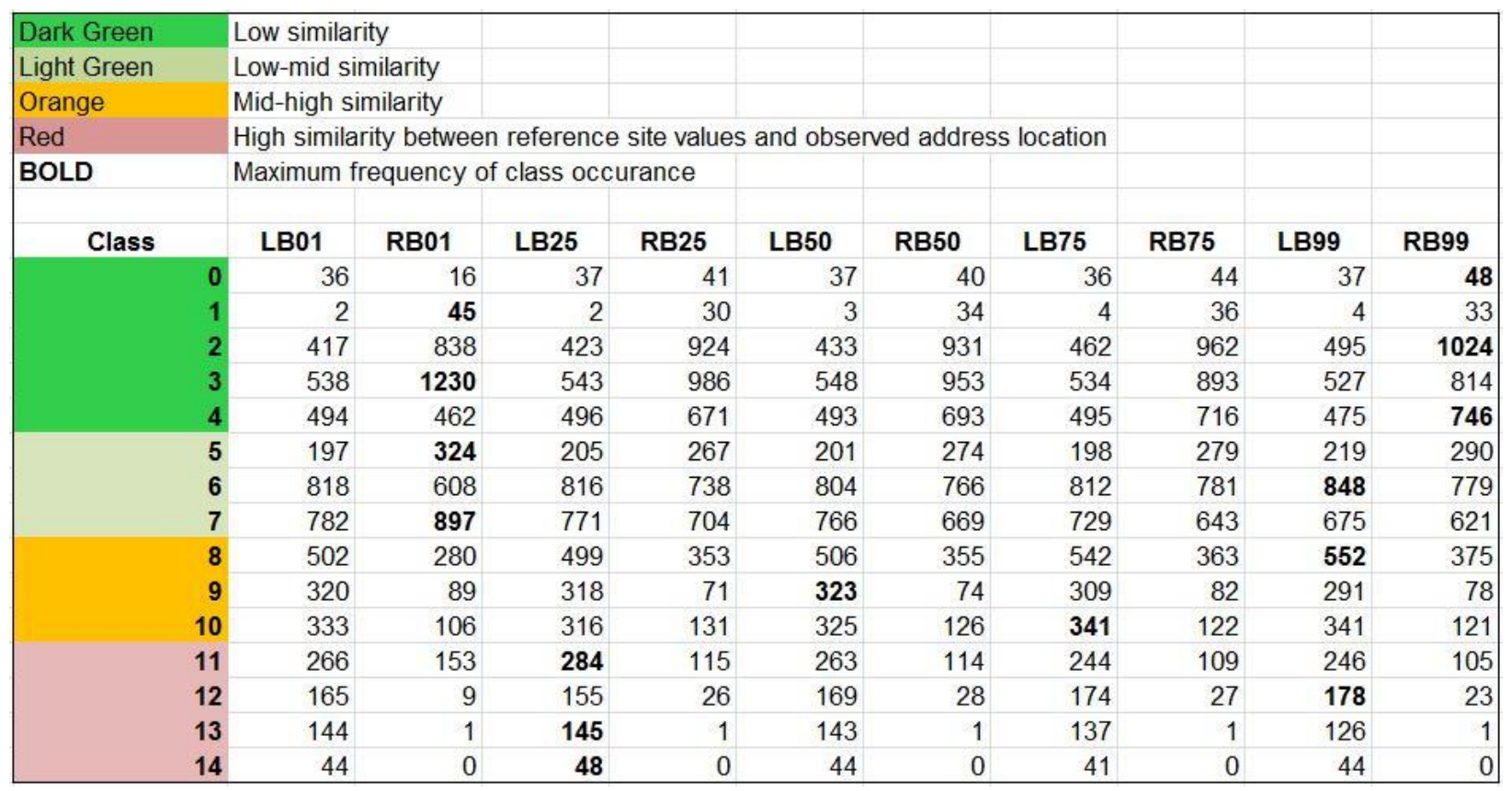

Table 1. Frequency of class occurrence and where the class ranks in terms of similarity.

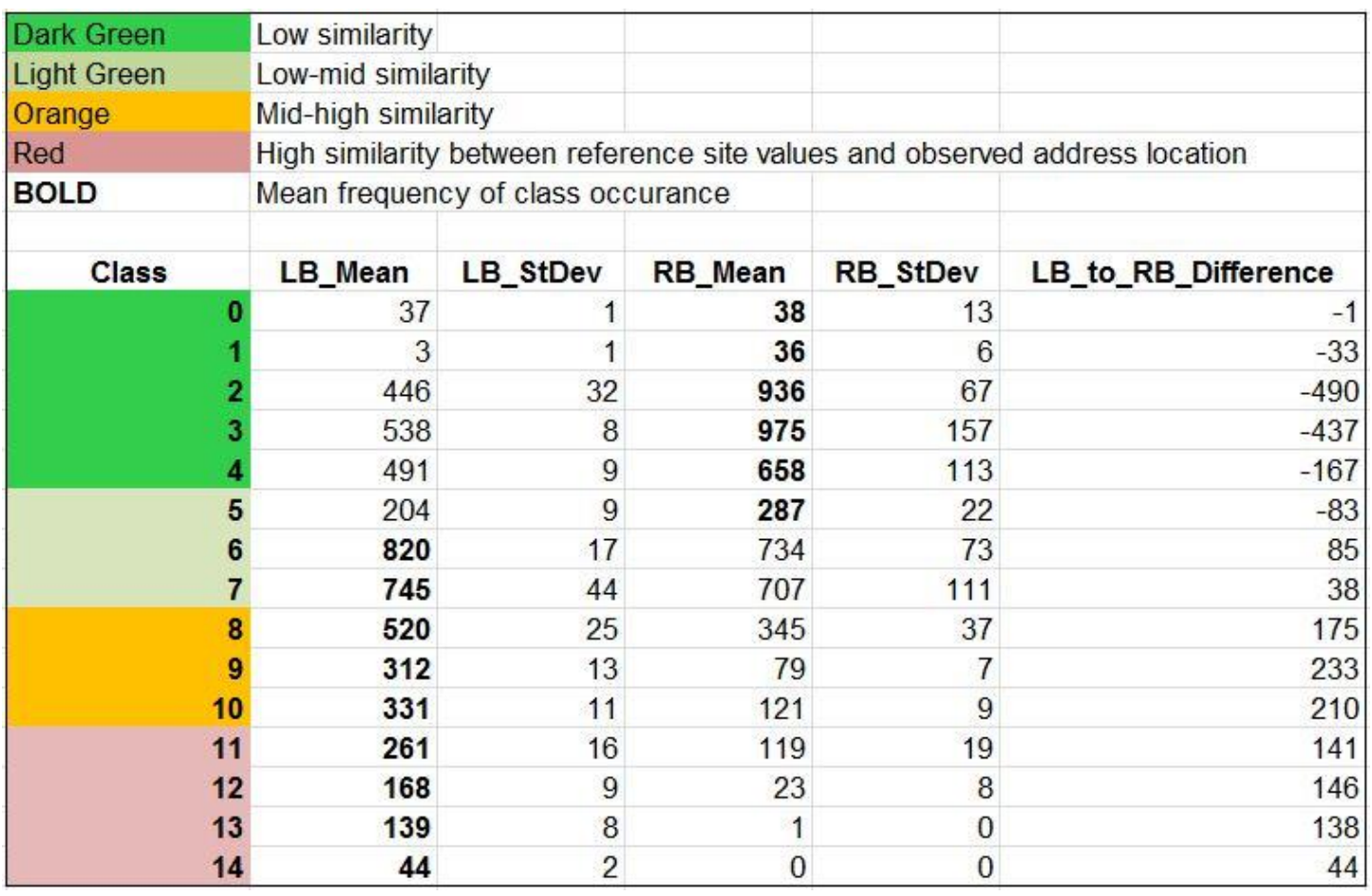

Table 2. Mean, standard deviation, and left-bank (LB) to right-bank (RB) differences for each class. 


\begin{tabular}{|c|c|c|c|c|c|c|c|c|c|c|}
\hline BOLD & Sum of frec & uency val & s in a de & criptive ele & nent & & & & & \\
\hline Class Rank & LB01 & RB01 & LB25 & RB25 & LB50 & RB50 & LB75 & RB75 & LB99 & RB99 \\
\hline Low similarity & 1487 & 2591 & 1501 & 2652 & 1514 & 2651 & 1531 & 2651 & 1538 & 2665 \\
\hline Low-mid similarity & 1797 & 1829 & 1792 & 1709 & 1771 & 1709 & 1739 & 1703 & 1742 & 1690 \\
\hline Mid-high similarity & 1155 & 475 & 1133 & 555 & 1154 & 555 & 1192 & 567 & 1184 & 574 \\
\hline High similarity & 619 & 163 & 632 & 142 & 619 & 143 & 596 & 137 & 594 & 129 \\
\hline
\end{tabular}

Table 3. Sum of frequencies for each flow scenario.

\subsection{Case Study Discussion and Conclusions}

Our geomorphic classification method provides a quantitative tool that can be used to relate habitat quality and biological integrity between different locations Based on our analysis of the lower Snake River using this tool, it is apparent that left bank habitat of the lower Snake River is preferable for juvenile salmon rearing compared to right bank habitat. This finding is consistent with existing information that suggests many highly suitable rearing areas are located on the left bank of the river and also that areas where new shallow water habitat has been created (i.e., Knoxway Bench) were located along the left bank(Arntzen et al. 2012).

Similarly, the classification identified geomorphic differences between locations where juvenile salmon have been shown to rear (e.g., at the Ilia Dunes, Offield Landing, Knoxway Bench, and Clarkston sites) versus other locations. Metric value ranges that were considered optimal were derived from the sites where juvenile salmonid abundance was high during the time of sampling. These findings are consistent with the results of Arntzen et al. (2012), who found that Shallowwater areas with a gradual lateral bed slope, especially at locations upstream of New York Island, harbored the most juvenile Chinook salmon of all sites examined in the lower Snake River. Water depth at these locations was typically less than $5 \mathrm{~m}$, contrasting with depths greater than $5 \mathrm{~m}$ found in $90 \%$ of Lower Granite Reservoir (Seybold and Bennett 2010). This result is generally consistent regardless of flow scenario, indicating that the potential exists to create additional shallow water habitat for juvenile salmonid rearing that will remain beneficial regardless of flow fluctuation.

\subsection{Alternative Hydrologic Classification Coupling}

\subsection{Hydrologic Classification Rationale}

Hydrologic classifications provide a means for developing environmental flow standards to support ecological management objectives in river systems (Arthington et al. 2006; Poff et al. 2010). Hydrologic classes also provide a template to describe ecological patterns, generalize hydrologic responses to disturbance, stratify analyses, and prioritize conservation needs.

Streams that behave similarly hydrologically should share similar patterns in ecology (Arthington et al. 2006) and respond similarly to a given anthropogenic stressor (Arthington et al., 2006; Poff et al., 2010). Thus, classifications alleviate some of the complexity of environmental flow management by consolidating hydrologic variation into river types and managing for groups of rivers rather than for the uniqueness of individual water bodies. 
In terms of managing flows for regulated river systems, hydrologic classes provide a contextual and quantitative basis for developing environmental flow standards by establishing boundaries that define unregulated or "natural" conditions (Richter, 2010). By placing regulated rivers into hydrologic classes, the degree of departures from the natural flow condition can provide an initial template for determining more environmentally friendly flow scenarios. This is especially advantageous in situations where discharge records are not available prior to dam construction (i.e. pre-disturbance conditions). Classes are also convenient in that they provide a range of "normal" conditions rather than just one value to support developing environmentally friendly flow scenarios. However, alternative flow scenarios must be developed in conjunction with other classifications (e.g. geomorphic classifications) and followed by studies that determine 1) the feasibility of implementing such alternatives, 2) the potential gains to ecological integrity, and 3) the potential losses to hydropower generation.

\subsection{US Hydrologic Classification and Predictive Models}

Hydrologic classes for the continental US were created using discharge information from 2,618 USGS gaging stations, which included gages with reference condition, semi-reference condition, and pre-dam regulation information (McManamay et al. in review). Discharge information for each USGS gage was downloaded and summarized into 171 hydrologic statistics (Olden and Poff 2003) using software from the USGS. Statistics were reduced to 110 metrics, standardized, and then used in a clustering procedure, which isolated 15 different hydrologic classes ranging from intermittent to highly stable flows. Random forests (i.e. multivariate predictive models) were used to predict hydrologic class membership based on landscape and climate variables (McManamay et al., in review). The random forests classified $76 \%$ of gages to their correct hydrologic classes. Thus, random forests can be used to classify locations without discharge information or disturbed gages to an unregulated hydrologic class. Extrapolating hydrologic class membership to unclassified locations can be highly advantageous in determining the degree of hydrologic alterations, especially in situations where natural flow information is missing (e.g. regulated systems lacking pre-dam data).

\subsection{Application of Hydrologic Classification in Determining Environmental Flows}

The degree of hydrologic alteration in regulated gages can be determined by 1) assigning disturbed gages to appropriate unregulated hydrologic classes based on landscape/climate predictive models and 2) assessing deviation in hydrologic metrics from each regulated gage to class median or inter-quantile ranges. By assembling landscape or climate information, regulated river systems can be assigned to hydrologic classes anywhere in the continental US using the random forest model. Once regulated rivers are assigned to an unregulated hydrologic class, current flow conditions can be compared to the range of values found within the class to assess the degree of hydrologic alteration. Based on degrees of hydrologic alterations and geomorphic context (e.g. geomorphic classifications), relationships between flow levels and ecological targets (e.g. species of concern) can be used to create alternative flow scenarios. Alternative flow scenarios might include re-establishing flood flows, changing seasonal baseflow magnitudes, or changing the frequency/duration of flows. 
While hydrologic classifications provide information on flow patterns, geomorphic classifications provide a reach-specific context to predicting physical habitat responses to changes in flow. For example, increasing flood flows may influence substrate conditions, and in turn, river communities, differently depending on geomorphic class membership. High gradient geomorphic classes may show losses in fish spawning habitats relative to lower-gradient classes. Hydrologic classes can be applied to regulated river systems across the US to provide alternatives for environmental flows; however, information on geomorphology is required to determine relationships between hydrology and river communities. Furthermore, alternative flow scenarios, when used in conjunction with geomorphic classes, can support modeling to determine the feasibility of implementing new flows. Feasibility assessments would include determining ecological benefits of instituting environmentally friendly flows relative to less economic return.

\subsection{Discussion and Conclusions}

The GIS framework for geomorphic classification of large rivers presented in this paper provides a method to evaluate flow-ecology relationships for large rivers within a flexible and accurate platform. The literature review of classification methods indicated that a framework that supported multiple analysis techniques would be the best choice to achieve the desired objective to have a geographically independent classification system. A diverse range of spatial scales was also important to capture variability within the area of analysis. This framework provides the user with the ability to classify a river system from reach to entire system scale by using the concept of address locations to store locally prescribed attribute values. River systems can also be compared using baseline data or statistically derived metrics.

An important addition to the framework was the ability to combine ecologic and hydraulic data with the base geomorphic aspect of the framework. Combining geomorphic, hydraulic, and ecologic metrics is easily calibrated using ecologic field data. A main motivation for using a river classification framework is to maximize understanding about a river system based upon data that is present for some smaller areas that may not be prevalent for the entire system. The lower Snake River case study represented in this paper gives one example of how to accomplish an interpretive effort using minimal field data.

Hydraulic metrics of interest were generated using the MASS2 model for the case study presented. However, other hydraulic models and classification systems could easily be combined with this GIS framework. In particular, hydrologic classifications that can be used throughout the contiguous United States are an excellent complement to this particular framework. The US Hydrologic Classification (McManamay et al. in review) presented in this paper as an alternative coupling to the base geomorphic aspect of this framework provides an example of a geographically independent classification system that could easily be coupled with this framework.

Future applications of this classification framework are to utilize it in other large river systems throughout the contiguous United States. The framework also allows for the organization of large river data to be quickly accessed and used for multi-river comparison and analysis. The 
development of a backend database accompaniment within an interactive web platform would be highly beneficial to create a readily available and standardized mechanism to facilitate nationally spread classification efforts. 


\subsection{References}

Arntzen EV, Klett K, Miller B, Mueller R, Harnish R, Nabelek M, Dauble D, James B, Scholz A, Paluch M, Sontag D, and Lester G. 2012. Habitat Quality and Fish Species Composition/Abundance at Selected Shallow-Water Locations in the Lower Snake River Reservoirs, 2010-2011 -- Final Report. PNWD-4325, Battelle--Pacific Northwest Division, Richland, Washington.

Arthington A, Bunn S, Poff N, Naiman R. 2006. The challenge of providing environmental flow rules to sustain river ecosystems. Ecological Applications, 16, 1311-1318. http://dx.doi.org/10.1890/1051-0761(2006)016[1311:TCOPEF]2.0.CO;2

Bennet D, Shrier F. 1986. Effects of Sediment Dredging and In-Water Disposal on Fishes in Lower Granite Reservoir, ID-WA. U.S. Army Corps of Engineers, Walla Walla District, Walla Walla, Washington.

Bennett DH, Dunsmoor L, and Chandler J. 1988a. Fish and Benthic Community Abundance at Proposed In-Water Disposal Sites, Lower Granite Reservoir. U.S. Army Corps of Engineers, Walla Walla District, Walla Walla, Washington.

Bennet DH, Dunsmoor L, and Chandler J. 1990. Lower Granite Reservoir In-Water Disposal Test: Results of the Fishery, Benthic, and Habitat Monitoring Program - Year 1 (1988). U.S. Army Corps of Engineers, Walla Walla District, Walla Walla, Washington.

Bennett DH, Chandler J, and Chandler G. 1991. Lower Granite Reservoir In-Water Disposal Test: Results of the Fishery, Benthic and Habitat Monitoring Program - Year 2 (1989). U.S. Army Corps of Engineers, Walla Walla District, Walla Walla, Washington.

Bennett DH, Dresser Jr T, Curet T, Lepla K, and Madsen M. 1993a. Lower Granite Reservoir In-Water Disposal Test: Results of the Fishery, Benthic and Habitat Monitoring Program - Year 3 (1990). U.S. Army Corps of Engineers, Walla Walla District, Walla Walla, Washington.

Bennett DH, Dresser J, Curet T, Lepla K, and Madsen M. 1993b. Lower Granite Reservoir In-Water Disposal Test: Results of the Fishery, Benthic and Habitat Monitoring Program - Year 4 (1991). U.S. Army Corps of Engineers, Walla Walla District, Walla Walla, Washington.

Brandt, S. 2000. Classification of geomorphological effects downstream of dams. Catena, 40, 375-401. http://dx.doi.org/10.1016/S0341-8162(00)00093-X

Brenden T, Wang L, Seelbach P, Clark Jr. R, Wiley M, and Sparks-Jackson, BL. 2008. A spatially constrained clustering program for river valley segment delineation from GIS digital river networks. Environmental Modelling \& Software, 23, 638-649. doi:10.1016/j.envsoft.2007.09.004 
Brierley G, Fryirs K. 2000. River styles, a geomorphic approach to catchment characterization: impacts for river rehabilitation in Bega catchment, New South Wales, Australia. Environmental Management, 25(6), 661-679. doi: 10.1007/s002670010052

Dauble D, Hanrahan T, Geist D, and Parsley M. 2003. Impacts of the Columbia River hydroelectric system on main-stem habits of fall Chinook salmon. North American Journal of Fisheries Management, 23, 641-659.

Frissell C, Liss W, Warren C, and Hurley M. 1986. A hierarchical framework for stream habitat classification: viewing streams in a watershed context. Environmental Management, 10(2), 199-214. http://dx.doi.org/10.1007/BF01867358

Graf W. 1996. Geomorphology and policy for restoration of impounded American rivers: what is 'natural?'. In B. Rhoads, \& C. Thorn, The scientific nature of geomorphology: proceedings of the 27th Binghampton symposium in geomorphology, held 27-29 September, 1996 (pp. 443-473). New York: John Wiley \& Sons.

Hanrahan T, Neitzel D, and Richmond M. 2003. Channel morphology and hydraulic characteristics in the lower Snake River prior to impoundment. Unpublished.

Hersh E, Maidment D. 2007. An integrated stream classification system for Texas. The University of Texas at Austin, Bureau of Engineering Research.

Higgins J, Bryer M, Khoury M, and Fitzhugh T. 2005, April. A freshwater classification approach for biodiversity conservation planning. Conservation Biology, 19(2), 432-445. doi:10.1111/j.1523-1739.2005.00504.x

Jacobson R, Elliot C, and Huhmann B. 2010. Development of a channel classification to evaluate potential for cottonwood restoration, lower segments of the Middle Missouri River, South Dakota and Nebraska. U.S. Geological Survey, Reston, Virginia.

Jenks G. 1967. The data model concept in statistical mapping. International Yearbook of Cartography 7, 186-190.

Kellerhals R, Church M, and Bray D. 1976. Classification and analysis of river processes. Journal of the Hydraulics Division, Proceedings of the American Society of Civil Engineers, 102, 813-829.

Maxwell J, Edwards C, Jensen M, Paustian S, Parrott H, and Hill D. 1995. A hierarchical framework of aquatic ecological units in North America (nearctic zone). US Forest Service, North Central Forest Experiment Station. St. Paul, MN: US Department of Agriculture.

McKay L, Bondelid T, Dewald T, et al. 2012. NHDPlus Version 2: user guide.

McManamay RA, Bevelhimer MS, and Kao S-C. 2013. A new US hydrologic classification: A tool to stratify analyses in ecohydrology. Ecohydrology (in review). 
National Agriculture Imagery Program. 2012. Retrieved from http://www.fsa.usda.gov/FSA/apfoapp?area=home\&subject=prog\&topic=nai

NHDPlus Version 2. 2012. Retrieved from http://www.horizon-systems.com/nhdplus/

Olden JD, Poff NL. 2003. Redundancy and the choice of hydrologic indices for characterizing streamflow regimes. River Research and Applications, 19, 101-121. doi: 10.1002/rra.700

Overwatch Systems. 2012. Retrieved from http://www.featureanalyst.com/

Perkins W, Richmond M. 2007. MASS2, Modular Aquatic Simulation System in two dimensions, theory and numerical methods. PNNL-14820-1, Pacific Northwest National Laboratory, Richland, WA.

Poff NL, Richter BD, Arthington AH, Bunn SE, Naiman RJ, Kendy E, Acreman M, Apse C, Bledsoe BP, Freeman MC, Henriksen J, Jacobson RB, Kennen JG, Merritt DM, O'Keeffe JH, Olden JD, Rogers K, Tharme RE, Warner A. 2010. The ecological limits of hydrologic alteration (ELOHA): a new framework for developing regional environmental flow standards. Freshwater Biology, 55, 147-170. doi: 10.1111/j.13652427.2009.02204.x

Reidy Liermann C, Olden J, Beechie T, Kennard M, Skidmore P, Konrad C, Imaki H. 2011. Hydrogeomorphic classification of Washington State rivers to support emerging environmental flow management strategies. River Research and Applications,28(9), 1340-1358. doi: 10.1002/rra.1541

Rakowski CL, JA Serkowski, MC Richmond, and WA Perkins. 2010. Determining Columbia and Snake River Project Tailrace and Forebay Zones of Hydraulic Influence using MASS2 Modeling. PNNL-20030, Pacific Northwest National Laboratory, Richland, WA.

Richter BD. 2010. Re-thinking environmental flows: from allocations and reserves to sustainability boundaries. River Research and Applications 26: 1052-1063. doi:10.1002/rra.1320

Richmond, MC, Perkins, WA, Scheibe, TD. 1999. Two-Dimensional Simulation of Hydrodynamics, Water Quality, and Fish Exposure in the Columbia/Snake River System. Waterpower Conference 1999 Las Vegas, Nevada, United States July 6-9, 1999. http://dx.doi.org/10.1061/40440(1999)48

Rosgen D. 1996. Applied River Morphology. Pagosa Springs, CO: Wildland Hydrology.

Rowntree K, Wadeson R. 1998. A geomorphological framework for the assessment of instream flow requirements. Aquatic Ecosystem Health and Management, 1(2), 125-141. doi:10.1080/14634989808656910

Seybold WF and DH Bennett. 2010. Inventory and Impact/Benefit Analyses of Sediment Disposal for Salmonid Fishes at Selected Sites in the Lower Snake River Reservoirs, Washington. U.S. Army Corps of Engineers, Walla Walla District, Walla Walla, Washington. 
Snelder T, Biggs B, Weatherhead M. 2004. New Zealand River Environment Classification Guide. National Institute of Water and Atmospheric Research. Wellington: Ministry for the Envrionment.

Thorp J, Flotemersch J, Delong M, Casper A, Thoms M, Ballantyne F, Williams BS, O'Neill BJ, Haase C. 2010. Linking ecosystem services, rehabilitation, and river hydrogeomorphology. BioScience, 60(1), 67-74.

http://www.jstor.org/stable/10.1525/bio.2010.60.1.11

USACE. 2002. Dredged Material Management Plan and Environmental Impact Statement. U.S. Army Corps of Engineers, Walla Walla District, Walla Walla, Washington.

USACE. 2011. Water management anonymous FTP. U.S. Army Corps of Engineers. Available at http://www.nwd-wc.usace.army.mil/ttppub/ (November 2011).

Wagener T, Murugesu S, Troch P, Woods R. 2007. Catchment classification and hydrologic similarity. Geography Compass, 1/4, 901-931. doi: 10.1111/j.1749-8198.2007.00039.x

Wang L, Infante D, Esselman P, Cooper A, Wu D, Taylor W, Beard D, Whelan G, Ostroff A. 2011. A hierarchical spatial framework and database for the national river fish habitat condition assessment. Fisheries, 36(9), 436-449. doi:10.1080/03632415.2011.607075

Whited D, Stanford J, Kimball J. 2002. Application of airborne multispectral digital imagery to quantify riverine habitats at different base flows. River Research and Applications, 18, 583-594. doi: 10.1002/rra.695

Wyrick J, Klingeman P. 2011. Proposed fluvial island classificaiton scheme and its use for river restoration. River Research and Applications, 27, 814-825. doi: 10.1002/rra.1395 


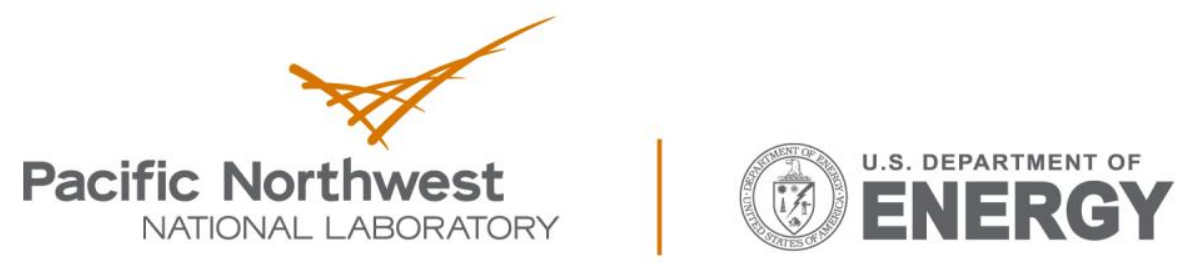

Proudly Operated by Battelle Since 1965

902 Battelle Boulevard

P.O. Box 999

Richland, WA 99352

1-888-375-PNNL (7665)

www.pnnl.gov 